\title{
RAPID REPRODUCTIVE ANALYSIS AND LENGTH-WEIGHT RELATIONS FOR FIVE SPECIES OF CORAL-REEF FISHES (ACTINOPTERYGII) FROM PAPUA NEW GUINEA: NEMIPTERUS ISACANTHUS, PARUPENEUS BARBERINUS, KYPHOSUS CINERASCENS, CTENOCHAETUS STRIATUS (PERCIFORMES), AND BALISTAPUS UNDULATUS (TETRAODONTIFORMES)
}

\author{
Ken LONGENECKER ${ }^{*}$, Ross LANGSTON ${ }^{1,2}$, Holly BOLICK ${ }^{1}$, Matthew CRANE ${ }^{3}$, \\ Terry J. DONALDSON ${ }^{4}$, Erik C. FRANKLIN ${ }^{5}$, Mildred KELOKELO ${ }^{4,6}$, Utula KONDIO ${ }^{7}$, \\ and Tapas POTUKU ${ }^{8}$ \\ ${ }^{1}$ Department of Natural Sciences, Bishop Museum, Honolulu, HI, USA \\ ${ }^{2}$ Department of Natural Sciences, Windward Community College, Kaneohe, HI, USA \\ ${ }^{3}$ Northern Marianas College, Saipan, CNMI, USA \\ ${ }^{4}$ University of Guam Marine Laboratory, Mangilao, GU, USA \\ ${ }^{5}$ Hawaii Institute of Marine Biology, School of Ocean and Earth Science and Technology, University of Hawaii,
} Kaneohe, HI, USA

${ }^{6}$ Wildlife Conservation Society, Kavieng, New Ireland Province, Papua New Guinea

${ }^{7}$ Kamiali Wildlife Management Area, Lababia, Morobe Province, Papua New Guinea

${ }^{8}$ The Nature Conservancy, Kavieng, New Ireland Province, Papua New Guinea

Longenecker K., Langston R., Bolick H., Crane M., Donaldson T.J, Franklin E.C., Kelokelo M., Kondio U., Potuku T. 2017. Rapid reproductive analysis and length-weight relations for five species of coral-reef fishes (Actinopterygii) from Papua New Guinea: Nemipterus isacanthus, Parupeneus barberinus, Kyphosus cinerascens, Ctenochaetus striatus (Perciformes), and Balistapus undulatus (Tetraodontiformes). Acta Ichthyol. Piscat. 47 (2): 107-124.

Background. We present length-weight relations (LWR) and describe the reproductive biology of five species of coral reef fishes from Papua New Guinea (PNG). Each of these species are targeted by artisanal- and smallscale commercial fisheries throughout the country. As such the purpose of this study was to provide baseline reproductive information that can be used for future evaluation and management of the fishery.

Materials and methods. We used recently developed methods for rapid, low-cost, on-site, histology-based reproductive analysis that requires minimal research infrastructure. These methods use standard techniques (e.g., plastic embedding) that have been modified such that work can be conducted in remote field settings without electrical service. We studied the following fish species: the teardrop threadfin bream, Nemipterus isacanthus (Bleeker, 1873); the dash-and-dot goatfish, Parupeneus barberinus (Lacepède, 1801); the blue sea chub, Kyphosus cinerascens (Forsskål, 1775); the striated surgeonfish, Ctenochaetus striatus (Quoy et Gaimard, 1825); and the orange-lined triggerfish, Balistapus undulatus (Park, 1797).

Results. In all species, length was an approximately cubic function of weight. Female B. undulatus mature at a smaller size than males; in the other four species males mature at a smaller size. Nemipterus isacanthus, $K$. cinerascens, $C$. striatus, and $B$. undulatus are gonochores. Females are rare or absent in the largest size classes of $N$. isacanthus, P. barberinus, $C$. striatus, and B. undulatus. For P. barberinus and B. undulatus, size classes well below maximum observed size are responsible for the majority of egg production.

Conclusion. Our results differed markedly from those of macroscopic and data-deficient approaches and may help to avoid unnecessary management actions. Further, an emergent pattern challenges a current paradigm in reef-fish conservation and management; contrary to a general assumption for many reef-fish species, the largest

* Correspondence: Dr. Ken Longenecker, Department of Natural Science, Bishop Museum, 1525 Bernice Street, Honolulu, HI, 96817 , USA, phone: +1 808 847 8273, fax +1808847 8252, e-mail: (KL) klongenecker@bishopmuseum.org, (RL)langston@hawaii.edu, (HB) holly@bishopmuseum.org, (MC)matthewrcrane75@gmail.com, (TJD)tdonaldson@triton.uog.edu, (ECF)erik.franklin@hawaii.edu, (MK) mildredkelokelo@gmail.com, (TP) tpotuku@tnc.org. 
size classes of at least three species did not have the highest per-capita fecundity. Because females were rare or absent in the largest size classes, smaller fish are responsible for the majority of egg production. Thus, for coastal communities dependent upon reef fishes for sustenance, our results suggest it may be easier to balance food needs and conservation by fishing across a broad size range. Further, because of diminished concern about targeting the larger size classes commonly assumed to be responsible for the majority of egg production, doing so will simultaneously promote adequate reproductive output.

Keywords: size-at-maturity, sexual pattern, sex ratios, batch fecundity, Jungle Histology

\section{INTRODUCTION}

Subsistence and small-scale commercial fishing of shallow-water coral reef fishes are important sources of food and income throughout the Pacific region (Roberts and Polunin 1993, Tokeshi et al. 2013, Rhodes et al. 2015). However, with new technologies and increasing human populations, there is growing concern that coral-reef fisheries are being overexploited (Friedlander and DeMartini 2002, Pandolfi et al. 2003, McClanahan et al. 2008).

One of the most-easily understood concepts to promote sustainable fishing practices is to harvest coral reef fish only after they have grown large enough to reproduce, and thus allow each generation to "seed" the next (Froese 2004). However, basic reproductive information (e.g., size at maturity) is lacking for most exploited fishes (Froese and Binohlan 2000, Rhodes and Tupper 2007) and the deficiency is especially acute for coral-reef-associated fishes. The sheer diversity of coralreef fishes and the supposed cost associated with the reproductive analysis of each species are often cited as barriers to obtaining this important information (Roberts and Polunin 1993, Johannes 1998). Further, many Pacific island nations, where many of the world's coral reefs are located, have little or no capacity to conduct reproductive research (Dalzell 1998, Rhodes et al. 2008). The reason for the latter problem may be as simple as a lack of basic infrastructure (e.g., electrical service needed to operate laboratory equipment) in many parts of these developing countries. These problems hinder current abilities to effectively manage coral-reef fisheries in the Pacific.

Advances in knowledge of the reproductive biology of Indo-Pacific reef fishes are ongoing (DeMartini et al. 2014, Shimose and Nanami 2014, 2015, Taylor et al. 2014, Ohta and Ebisawa 2015, DeMartini and Howard 2016, Rhodes et al. 2016, Schemmel et al. 2016, Taylor et al. 2016). However, none of these studies use histological methods that can be readily employed in developing countries (with limited research infrastructure) and easily learned by local marine resource-management staff (who often may be inadequately trained).

To address these challenges, Longenecker et al. (2013a) developed a method for rapid, low-cost, onsite, histology-based reproductive analysis that requires minimal research infrastructure. The method has since earned the appellation "Jungle Histology", which describes the environment for which the method was developed and hints at the "guerrilla" nature of the approach. The method focuses upon histological examination because other means of estimating reproductive parameters have welldemonstrated biases. The FishBase life history tool (Froese and Pauly 2016), built on the empirical relations of Froese and Binohlan (2000), increasingly overestimates female size-at-maturity as the maximum size of a species increases (Longenecker et al., 2013b, Longenecker and Langston 2016). Visual (macroscopic) examination of gonads results in misclassification of sex and/or reproductive status in 43\%-47\% of specimens (Longenecker et al. 2013a, 2013c). These misclassifications tend to overestimate the number of mature females (Longenecker et al. 2013a, 2013c), underestimate female size-at-maturity (Grandcourt et al. 2006, 2011), and overestimate female spawning biomass (Vitale et al. 2006). Additionally, histological analysis is required to diagnose sex change (Sadovy and Shapiro 1987).

With the Jungle Histology method, reproductive information can be generated quickly and its low cost eliminates one of the arguments against broad-scale reproductive analysis surveys. Also, the simple methods can be easily learned by marine resource-management staff, thus increasing the capacity for "home grown" reproductive analysis in developing countries or in places with little or no research infrastructure or capability. The purpose of this article is to present the reproductive information generated during a Jungle Histology training workshop for natural resource professionals from USassociated Pacific Islands and Papua New Guinea. The goal of that workshop was to develop a cadre of fish reproductive biologists who can independently use the Jungle Histology method, thus increasing the rate at which new reproductive information is generated, and increasing the potential to effectively manage and conserve Pacific coral-reef fishes.

Workshop participants chose study species that were:

- Wide-ranging;

- Heavily exploited in some part of their range;

- Distinctive enough that the chance of misidentification is low; and

- Whose reproductive biology was studied little or not at all.

Published reproductive information is lacking or incomplete for the dash-and-dot goatfish, Parupeneus barberinus (Lacepède, 1801); the blue sea chub, Kyphosus cinerascens (Forsskål, 1775); the striated surgeonfish, Ctenochaetus striatus (Quoy et Gaimard, 1825); and the orange-lined triggerfish, Balistapus undulatus (Park, 1797). All four species are distinctive, widespread in the tropical Indo-West Pacific (Matsuura 2001, Randall 2001a, 2001b, Sakai 2001) and are heavily targeted reef-fishery species (McClanahan et al. 1999, Grandcourt 2002, Rhodes et al. 2008, Crawford et al. 2011, Feary et al. 2011, Ochavillo et al. 2011, Houk et al. 2012). 
Additionally, a subset authors (KL, RL, HB, and UK) analysed a fifth species, the teardrop threadfin bream, Nemipterus isacanthus (Bleeker, 1873), for which there appears to be no published reproductive information. Until recently, $N$. isacanthus was reported to have a West Pacific distribution, including the Gulf of Thailand; waters surrounding the Philippine and Indonesian islands; and the north-western coast of Australia (Russell 1990). However, we studied a large, permanent population recently documented at Kamiali Wildlife Management Area (KWMA), Morobe Province, Papua New Guinea, representing the easternmost known limit of the species, where it forms a large part of the subsistence fish catch (Longenecker and Giamsa 2016). Reports from elsewhere indicate that $N$. isacanthus appears occasionally in small numbers in local markets, although there is no major fishery for the species (Russell 1990).

\section{MATERIALS AND METHODS}

We used methods modified from Longenecker et al. (2013a) to describe length-weight relations, size-atmaturity, sexual pattern, sex-ratios, and length-batch fecundity relations*. The modifications were designed to decrease the total volume of fixative used in histological processing and greatly decrease the time necessary for fecundity estimates.

Specimen acquisition and whole specimen processing. Workshop specimens (Parupeneus barberinus, Kyphosus cinerascens, Ctenochaetus striatus, and Balistapus undulatus) were purchased from local fishers near Kavieng, New Ireland Province, Papua New Guinea (Fig. 1). All acquisitions were made in accordance with local laws and regulations. Special permits were not required because the specimens were purchased directly from markets and not exported out of the country. For each specimen, length from the front of the head with mouth closed to the end of the middle caudal ray, was measured to the nearest $0.1 \mathrm{~cm}$. Whole body weight was measured with the smallest-possible of two hanging spring-scales (100 or $1000 \mathrm{~g}$ capacity, with 1 or $10 \mathrm{~g}$ increments, respectively), with the exception of seven juvenile $B$. undulatus that were weighed on a batterypowered jeweler's scale to the nearest $0.001 \mathrm{~g}$. A midventral incision was made from the vent through the pelvic girdle, sex and reproductive status (based on gross examination) were recorded, then gonads were excised and weighed to $0.001 \mathrm{~g}$ on a battery-powered jeweler's scale. For each ovary that appeared, macroscopically, to be at or nearing maturity (late vitellogenesis through hydration, stage IIIb through $\mathrm{IVb}$, respectively), an approximately $1-\mathrm{cm}$ thick transverse section was removed from one lobe, weighed to $0.001 \mathrm{~g}$, and transferred to approximately $15 \mathrm{~mL}$ Gilson's fluid in a skirted $50-\mathrm{mL}$ centrifuge tube for later batch fecundity analysis (below). For all gonads (regardless of sex or reproductive status) an approximately $3 \mathrm{~mm} \times 3 \mathrm{~mm} \times 3 \mathrm{~mm}$ subsample was excised, placed in one well of a tissue culture plate, and fixed in Dietrich's solution for at least $24 \mathrm{~h}$.

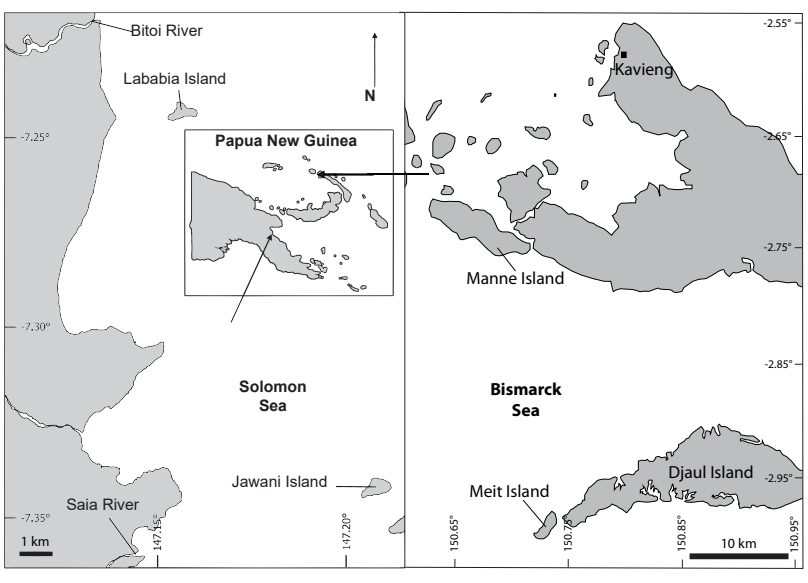

Fig. 1. Map of the sampling areas in Papua New Guinea; Specimens for the Jungle Histology workshop were obtained near Kavieng, New Ireland Province (right); Supplementary specimens of workshop species, and all Nemipterus isacanthus specimens, were obtained from Kamiali Wildlife Management Area, Morobe Province, located between the Bitoi and Saia Rivers (left)

Size-at-maturity and sexual pattern. The Dietrich'sfixed gonad subsamples were trimmed to a volume of approximately $8 \mathrm{~mm}^{3}(2 \mathrm{~mm} \times 2 \mathrm{~mm} \times 2 \mathrm{~mm})$, then dehydrated in ethanol (30-60 min in each of 50\%, and two changes of $95 \%$ ethanol). Using plastic embedding medium (JB-4, Electron Microscopy Sciences) and following kit instructions, gonad sections were infiltrated in two changes of infiltration solution $(1 \mathrm{~h}$ and $>8 \mathrm{~h}$, respectively), transferred into embedding capsules $(\mathrm{BEEM} \AA$, size 00$)$, and embedded in catalysed JB-4 solution. Because high humidity in tropical locations often prevents tissue blocks from hardening completely, tissue blocks were dehydrated for $12 \mathrm{~h}$ in a "desiccating chamber" (a diver's dry box containing silica gel packets and placed in full sunlight). From each embedded gonad subsample, 10 tissue sections (approximately 7- $\mu \mathrm{m}$ thick), distributed evenly throughout each tissue block, were obtained by serial sectioning on an MT1 PorterBlum microtome outfitted with a glass knife. The tissue sections were floated on water droplets distributed on microscope slides, and slides were dried on a "warmer" (a flat piece of thick metal placed in full sunlight). Tissue sections (now affixed to the slides) were stained in a $0.5 \%$ solution of Toluidine Blue in water for $15 \mathrm{~s}$. Excess stain was removed with a gentle stream of water, and the slides were once again dried on the "warmer". Ovary sections were examined at $100 \times$ and testis sections at $400 \times$ for evidence of reproductive maturity. Ovaries were classified according to Wallace and Selman (1981) and testes according to Nagahama (1983). Females were considered mature with the onset of vitellogenesis or when post-ovulatory follicles were present, and males mature when the testes contained visible spermatozoa (sperm cells with tails). 
Batch fecundity. Methods modified from Agger et al. (1974) were used to estimate batch fecundity. Ovarian samples reserved for batch-fecundity analysis (above) were hand-shaken at least once during each of 14 days. Batch fecundity estimates were generated for those that, based on the histological examination above, had reached the maturation or hydration stage (IVa or IVb, respectively). Oocytes were teased from the stroma, then the samples were diluted with water to a total volume of $400 \mathrm{~mL}$. The diluted sample was stirred to distribute oocytes, and a Stempel pipette was used to obtain ten 1-mL subsamples. Counts of oocytes in the largest size-class in each subsample were recorded, and batch fecundity (BF) was estimated with the following equation:

$$
\mathrm{BF}=\left(N_{\mathrm{o}} \cdot V\right)\left(W_{\mathrm{o}} \cdot W_{\mathrm{s}}^{-1}\right)
$$

where: $N_{\mathrm{o}}$ is the mean number of mature oocytes per $\mathrm{mL}, V$ is the total dilution volume in $\mathrm{mL}, W_{\mathrm{o}}$ is the total ovary weight, and $W_{\mathrm{s}}$ is the sample weight.

Supplementary specimens. Poor weather at Kavieng prevented fishing during much of the time allotted for reproductive analysis, with the result that fishers caught the overwhelming majority of specimens in a single day. Very few ovaries from these specimens contained stage IV eggs, making fecundity analysis difficult. To address this shortcoming, a subset of authors (KL, RL, HB, and UK) targeted the same species in later field work at KWMA (Fig. 1), and hoped to increase the number of gravid females in our sample size while adding more specimens to the other analyses. Additionally, all Nemipterus isacanthus specimens were collected at KWMA. Village residents, through regular fishing activities from 4 February-4 June 2015, caught specimens by hook-and-line. These specimens were caught as many as four months before histological processing (i.e., they could not be fully processed as they were captured). Because there is no electrical service (and thus specimens could not be frozen) at KWMA, gonads were fixed immediately after capture, resulting in the following differences from Kavieng data:

- Whole-gonad weights are for fixed tissues;

- Ovarian subsample weights for fecundity analysis are for fixed tissues; and

- Fixed ovarian subsamples were placed into Gilson's fluid for oocyte counts.

All of these steps were accomplished using fresh tissues in Kavieng.

Data analysis. We constructed length-weight relations (LWR) using log-transformed data and following the guidance of Froese et al. (2011). Because of evidence that a scale used at KWMA was inaccurate, we excluded KWMA length-weight data from the analyses for workshop species (Parupeneus barberinus, Kyphosus cinerascens, Ctenochaetus striatus, and Balistapus undulatus). However, more-detailed analysis indicated the measurement error was restricted to specimens weighing $<40 \mathrm{~g}$, thus the LWR for Nemipterus isacanthus (collected exclusively at $\mathrm{KWMA}$ ) is restricted to specimens $\geq 40 \mathrm{~g}$. For all species, we considered any data point in the length-weight regression with a residual $>0.125$ to be an outlier. We used analysis of covariance (ANCOVA) to evaluate whether the LWR varied between sexes. We report size at maturity $\left(L_{50}\right)$ as the size at which a non-linear regression (3-parameter, sigmoidal) of percent mature individuals versus length (the mean length of individuals within a 2-cm size class) indicates $50 \%$ of individuals are mature. We assigned onehalf of undifferentiated individuals to each sex. We used $\chi^{2}$ analysis to test whether overall sex ratios differed from 1 : 1. We described size-specific sex ratios by determining the percent of mature females (of total mature individuals) in each size class, then plotting $\%$ mature females as a function of mean length within each size class. We used exploratory regression analysis to evaluate whether sex ratios of mature individuals varied predictably with length. We tested for relations between length and batch fecundity using linear regression analysis of log-transformed data. We evaluated which part of a population is responsible for the majority of egg production by first multiplying the result of the lengthfecundity relation at a given length by the likelihood that an individual at that length is female (i.e., the size-specific sex ratio). We then plotted the product as a function of length. For comparative purposes, we assumed that the likelihood of an individual being female is constant across all lengths (using the overall sex ratio) and plotted the product as a function of length. Thus we standardized both curves to represent the expected batch fecundity of any randomly chosen individual of a given length (i.e., not just females).

\section{RESULTS}

Results are summarized in Table 1 and presented more fully in separate sections for each species, below.

Nemipterus isacanthus. ANCOVA did not detect a significant sex-based difference in the length-weight relation for this population $(F=0.28, \mathrm{DF}=1, P=0.598)$. Total body weight $(W)$ in $g$ was an approximately cubic function of fork length (FL) in cm (Table 1). The 95\% CI of regression parameters $a$ and $b$ were $0.00726-0.0133$ and 3.06-3.28, respectively $\left(r^{2}=0.977, n=81\right.$, FL range: 13.0-24.9, $W$ range: 40-250).

We histologically examined gonads of 84 male and 23 female Nemipterus isacanthus. Figure 2 shows the size-frequency distribution of each sex and maturity stage. Figure 3 shows examples of immature and mature testes and ovaries. Ovaries of mature females contained several discrete stages of oocytes, indicating groupsynchronous oocyte development (Wallace and Selman 1981). We therefore classified $N$. isacanthus as a batch spawner. Ovaries contained vitellogenic oocytes in females as small as $10.9 \mathrm{~cm}$ FL and all females $\geq 16 \mathrm{~cm}$ FL were mature. The smallest male with spermiated testes was $10.3 \mathrm{~cm}$ FL. Immature/inactive individuals were scattered throughout the male size range, with $90 \%$ of individuals $\geq 14.9 \mathrm{~cm}$ FL being mature. Figure 4 shows the relative frequency of reproductive states in each size class. Overall, $78.3 \%$ of females and $78.6 \%$ of males were mature. We had too few immature individuals to estimate $L_{50}$ for either sex. 


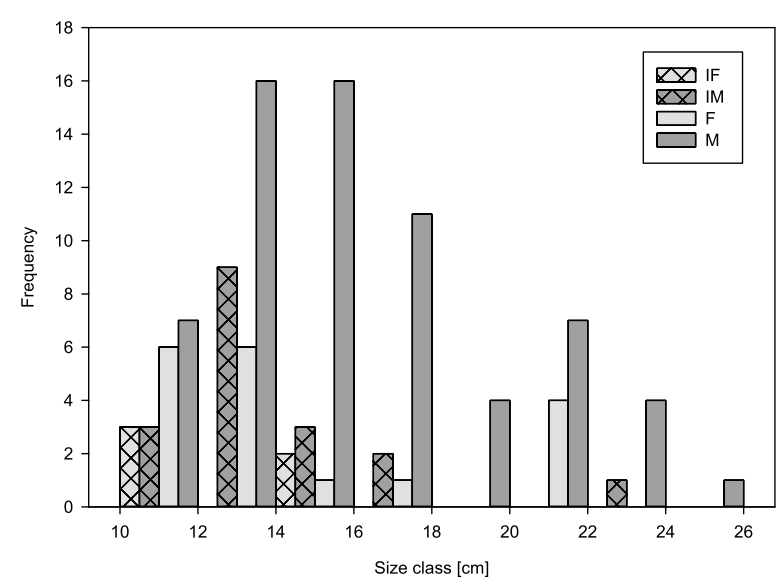

Fig. 2. Size-frequency plot of Nemipterus isacanthus specimens, with sex and maturity status determined by histological examination of gonads; IF = immature females, $\mathrm{IM}=$ immature males, $\mathrm{F}=$ mature females, $\mathrm{M}$ $=$ mature males

We did not see evidence of sex change in Nemipterus isacanthus. A $t$-test did not detect a significant sexbased difference in mean length $(t=-1.69, \mathrm{DF}=105$, $P=0.09)$. We did not see a central membrane-lined lumen in testes, or any gonad containing a mixture of ovarian and spermatogenic tissue. Nor did we observe a dorsal accessory duct, associated with rudimentary hermaphroditism in some Nemipterus species (Takahashi et al. 1989, Lau and Sadovy 2001). Based on the above, we classified $N$. isacanthus as a gonochore.

Overall sex ratio in this Nemipterus isacanthus population was male-biased (Table $1, \chi^{2}=34.8$, DF $=$ $1, P<0.0001$. Considering only mature individuals, the observed sex ratio was also significantly male-biased $\left(\chi^{2}=\right.$ $27.4, \mathrm{DF}=1, P<0.0001)$. However, the sex ratio of mature individuals varied predictably with length; although all classes were male biased, the highest percentage of females was found in the smallest size class (Fig. 5). An equation describing the percent of mature females $(\%$ ) , throughout the size range of mature specimens (Table $1, r^{2}=0.965$ ), predicts that the population was exclusively male when body size $\geq 22.5 \mathrm{~cm}$ FL.

Our gross-level (macroscopic) evaluations of oocyte stage were usually incorrect. We judged all but two specimens as being in early vitellogenesis (stage IIIa) or earlier stages of oogenesis. Later histological evidence indicated only one of the two ovarian samples we collected for fecundity analysis had reached stage IV, and that four other specimens for which we did not collect fecundityanalysis samples had reached stage IV (maturation or hydration). This gross-level error left us with too few samples $(n=1)$ to construct a length-batch fecundity relation.

Parupeneus barberinus. ANCOVA did not detect a significant sex-based difference in the length-weight relation for this population $(F=0.27, \mathrm{DF}=1, P=0.603)$. Total body weight $(W)$ in $g$ was an approximately cubic function of fork length (FL) in cm (Table 1). The 95\%

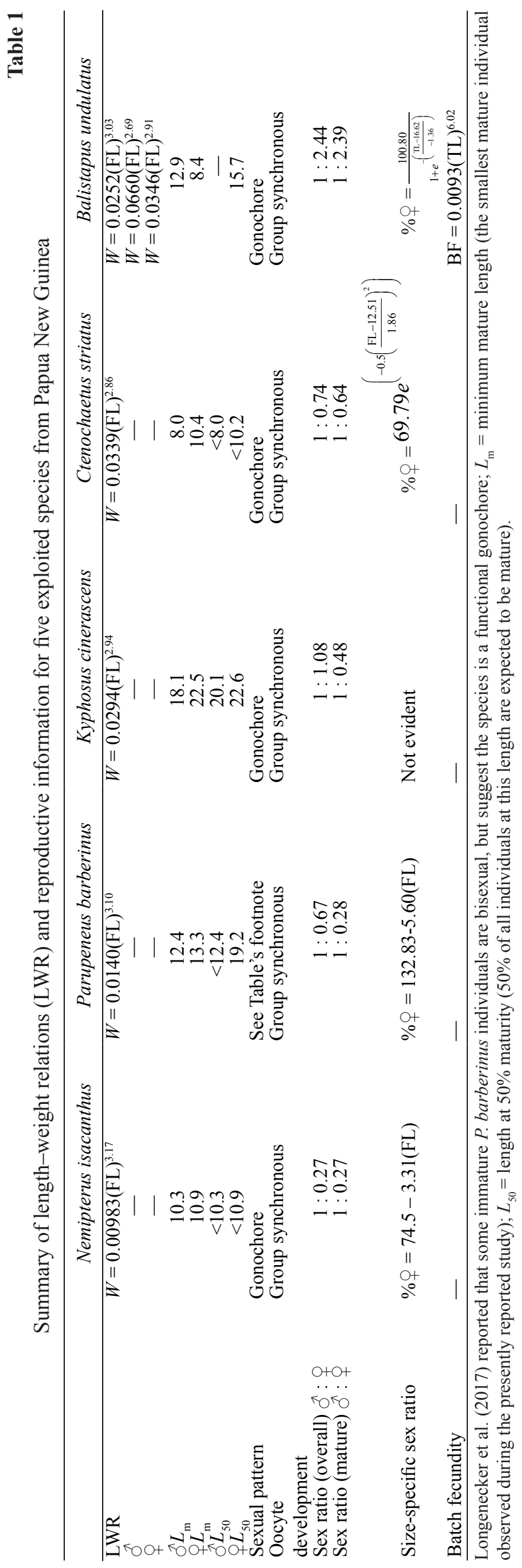



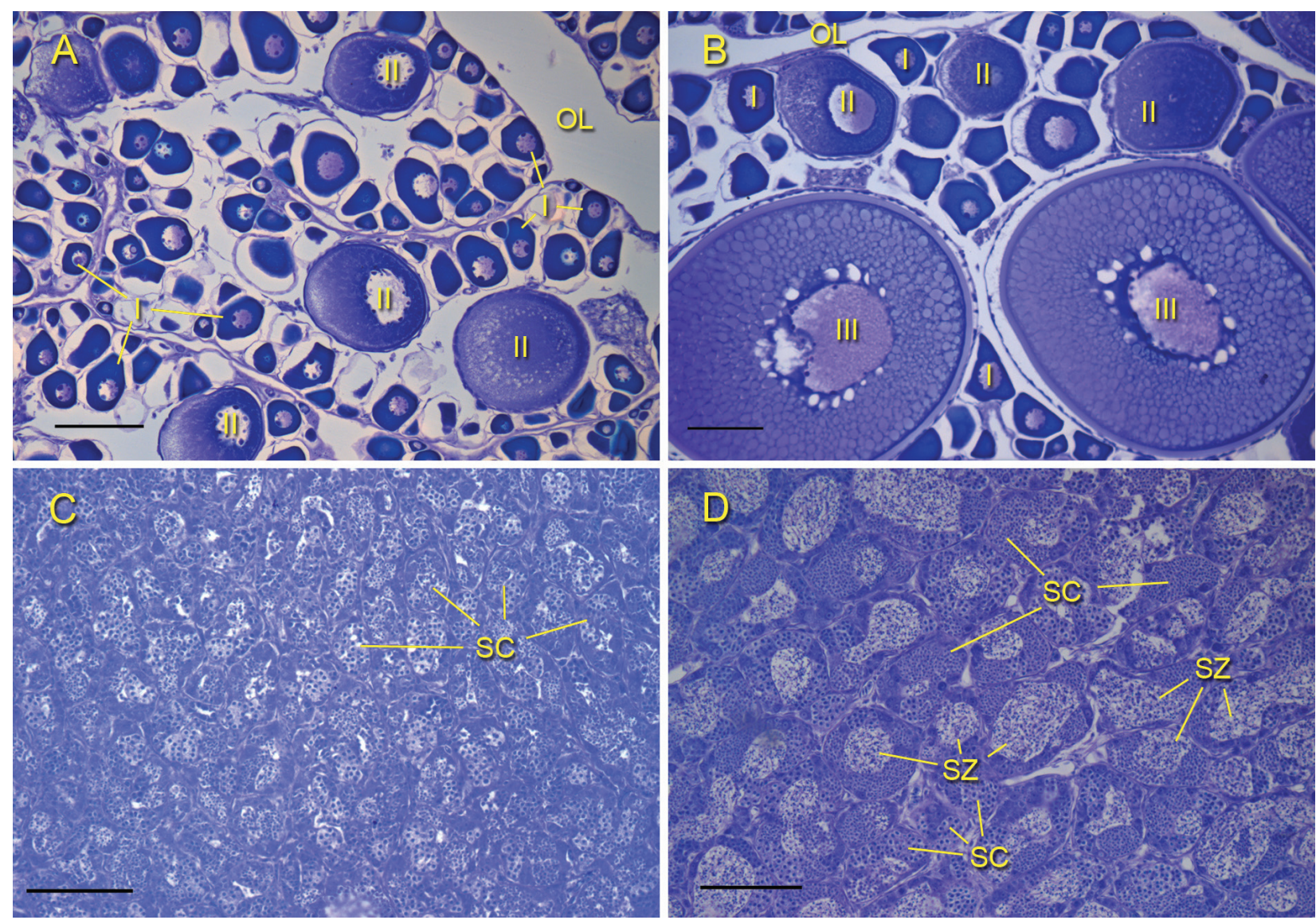

Fig. 3. Histological sections of gonads of teardrop threadfin bream, Nemipterus isacanthus, from the Kamiali Wildlife Management Area, Papua New Guinea: Ovary of immature female (A) $(14.1 \mathrm{~cm})$ containing primary-growth (I) and cortical vesicle (II) oocytes; Ovary of mature female (B) $(21.5 \mathrm{~cm})$ containing primary-growth (I), cortical vesicle (II), and vitellogenic (III) oocytes; Testis from an immature male $(\mathbf{C})(13.6 \mathrm{~cm})$ containing spermatogenic cysts (SC); Testis of a mature male (D) $(12.8 \mathrm{~cm})$ with spermatogenic cysts $(\mathrm{SC})$ and tailed spermatozoa (SZ); OL = ovarian lumen; scale bars $=100 \mu \mathrm{m}$

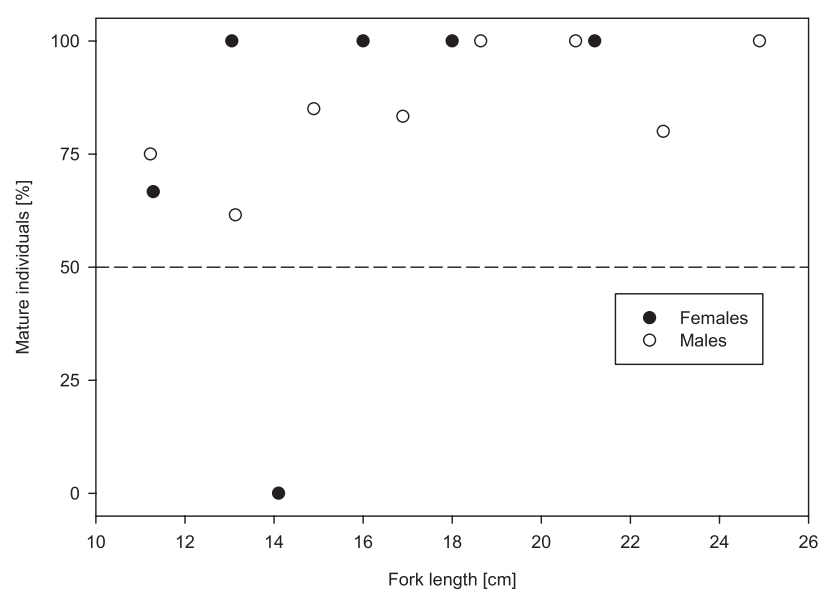

Fig. 4. Percent of mature individuals in each 2 -cm size class for teardrop threadfin bream, Nemipterus isacanthus, from the Kamiali Wildlife Management Area, Papua New Guinea

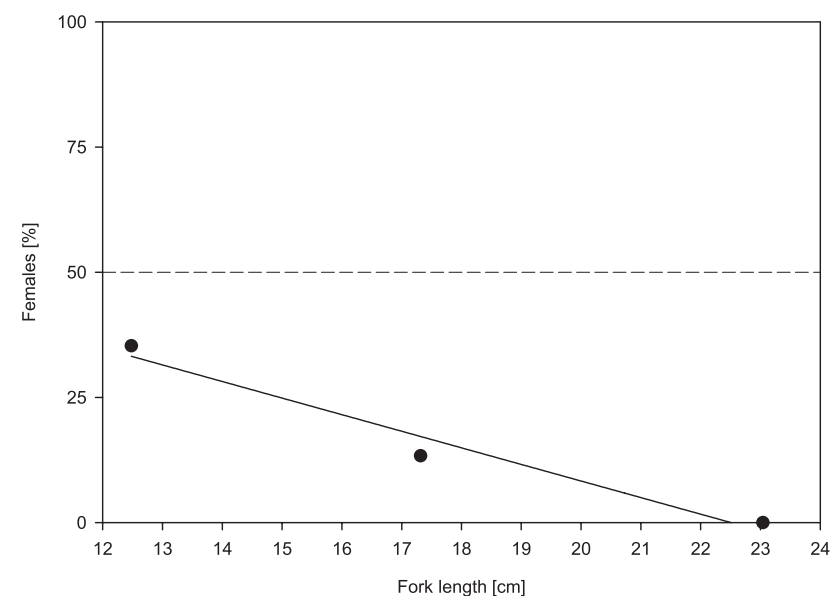

Fig. 5. Percentage of mature females, relative to all mature individuals, versus length for teardrop threadfin bream, Nemipterus isacanthus, from the Kamiali Wildlife Management Area, Papua New Guinea; The equation for the fitted line is given in Table $1\left(r^{2}=0.965, F=\right.$ $27.4, P=0.120$ ) 
CI of regression parameters $a$ and $b$ were $0.0113-0.0174$ and 3.02-3.17, respectively $\left(r^{2}=0.978, n=158\right.$, FL range: 12.5-25.3, $W$ range: $40-335)$.

We histologically examined gonads of 94 male, 62 female, and 8 bisexual Parupeneus barberinus. Figure 6 shows the size-frequency distribution of each sex and maturity stage. Figure 7 shows examples of immature and mature testes and ovaries. Ovaries of mature females contained several discrete stages of oocytes, indicating group-synchronous oocyte development (Wallace and Selman 1981). We therefore classified $P$. barberinus as a batch spawner. Bisexual individuals ranged from 16.1$22.5 \mathrm{~cm} \mathrm{FL}$, did not show evidence of functioning as either sex, and were omitted from size-at-maturity analyses. Ovaries contained vitellogenic oocytes in females as small as $13.3 \mathrm{~cm}$ FL. Inactive and immature females (range 11.7-19.9) were scattered throughout the size range of mature females (range 13.3-22.0). We estimate female $L_{50}$ at $19.2 \mathrm{~cm}$ FL (Fig. 8). The smallest male with spermiated testes was $12.4 \mathrm{~cm}$ FL. Inactive and immature males (range 12.8-24.8) were scattered throughout the size range of mature males (range 12.4-25.3). We could not generate a satisfactory $L_{50}$ curve for males, the percent of mature individuals was greater than $50 \%$ for all size classes sampled and the mean was $78.7 \%$ (Fig. 8 ).
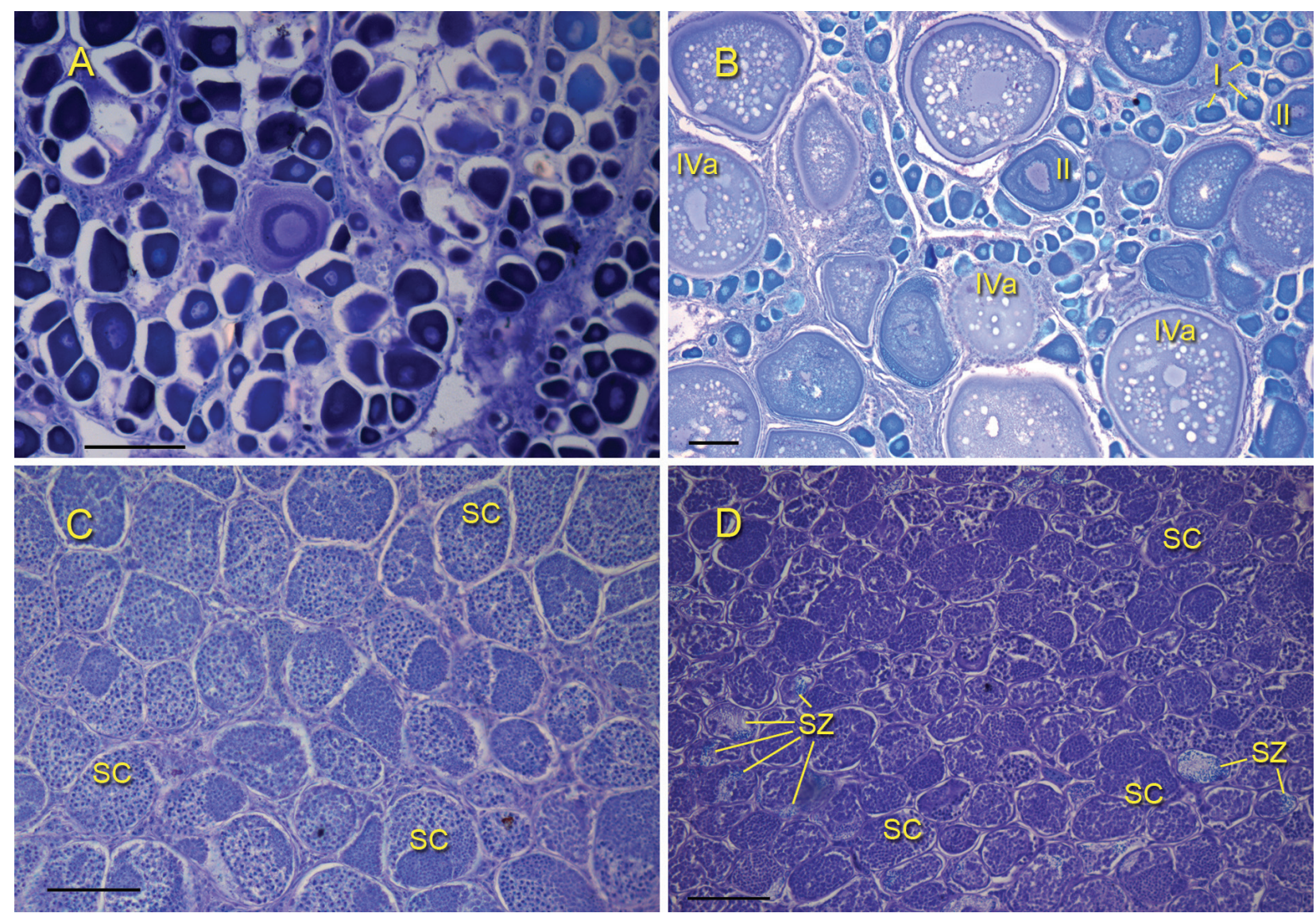

Fig. 7. Histological sections of gonads of dash-and-dot goatfish, Parupeneus barberinus, from Papua New Guinea: Ovary of immature female $(\mathbf{A})(13.0 \mathrm{~cm})$ containing only primary-growth oocytes; Ovary of mature female (B) $(18.0$ $\mathrm{cm}$ ) containing primary-growth (I), cortical vesicle (II), and final maturation (IVa) oocytes; Testis from an immature male $(\mathbf{C})(19.7 \mathrm{~cm})$ containing spermatogenic cysts $(\mathrm{SC})$; Testis of a mature male $(\mathbf{D})(22.0 \mathrm{~cm})$ with spermatogenic cysts (SC) and tailed spermatozoa (SZ); Scale bars $=100 \mu \mathrm{m}$ 


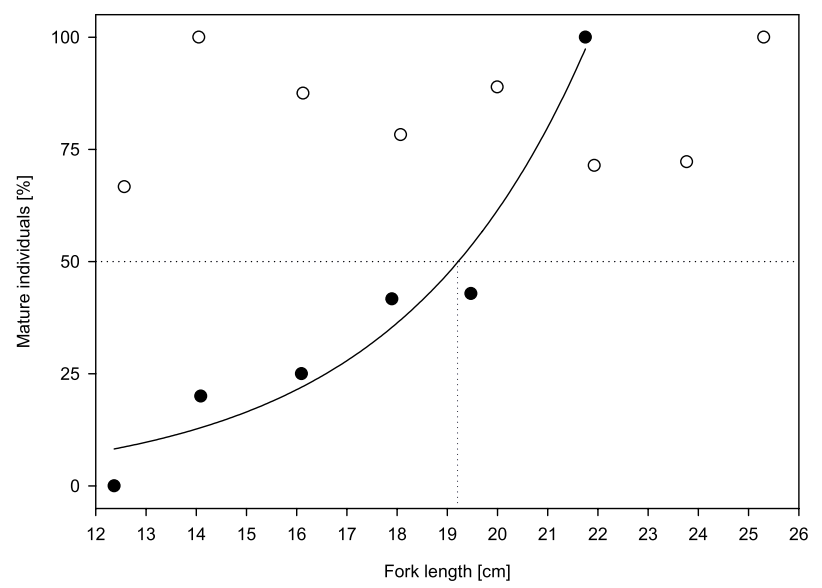

Fig. 8. Size-at-maturity $\left(L_{50}\right)$ for Parupeneus barberinus from Papua New Guinea; Females are represented by closed circles and the solid line $\left(r^{2}=0.951, F=28.9, P\right.$ $=0.011)$, males are represented by open circles

$\mathrm{DF}=1, P<0.001)$. However, the sex ratio of mature individuals varied predictably with length; the percentage of females was inversely proportional to length (Fig. 9). An equation describing the percent of mature females $(\%$ 웅, throughout the size range of mature specimens (Table 1, $r^{2}$ $=0.938$ ), predicts that the population was exclusively male when body size $>23.7 \mathrm{~cm}$ FL.

Linear regression analysis of log-transformed fecundity-at-length data was not significant $(F=0.632, n=$ $7, P=0.493)$; batch fecundity did not increase with length. However, batch fecundity ranged from 5286 and 44345 eggs in seven females ranging from 13.3 to $19.4 \mathrm{~cm}$ FL.

The curves in Fig. 10 show the relation between length and expected individual batch fecundity with observed overall sex ratios and with observed size-specific sex ratios (the curves incorporate the Parupeneus barberinus length-batch fecundity relation from Longenecker et al. 2011). With an assumed constant sex ratio, expected per individual egg production is greatest at maximum size. When size-specific sex ratios are considered, the small chance of an individual being a female eventually overwhelms increases in batch fecundity such that expected egg production per individual peaks at $18.2 \mathrm{~cm}$ FL, well below maximum observed length (Fig. 10, solid curve). Failing to account for size-specific sex ratios at the largest observed specimen size led to a 22 100-egg overestimate in expected individual batch fecundity.

Kyphosus cinerascens. ANCOVA did not detect a significant sex-based difference in the length-weight relation for this population $(F=1.20, \mathrm{DF}=1, P=0.282)$. Total body weight $(W)$ in $\mathrm{g}$ was an approximately cubic function of fork length (FL) in cm (Table 1). The 95\% CI of regression parameters $a$ and $b$ were $0.0187-0.0462$ and 2.79-3.08, respectively $\left(r^{2}=0.979, n=38\right.$, FL range: $15.8-30.7, W$ range: $101-660)$.

We histologically examined gonads of two (2) undifferentiated, 26 male, and 28 female Kyphosus cinerascens. Figure 11 shows the size-frequency distribution of each sex and maturity stage. Figure 12

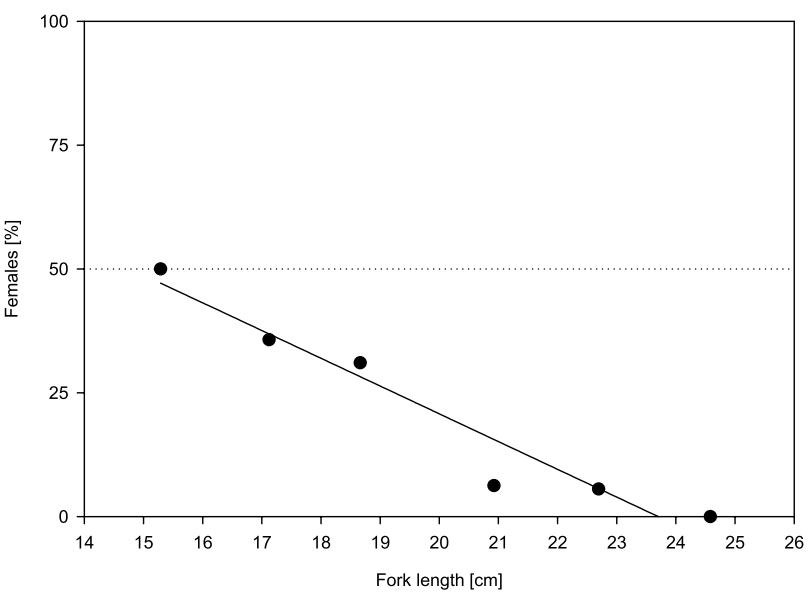

Fig. 9. Percentage of mature females, relative to all mature individuals, versus length for Parupeneus barberinus from Papua New Guinea; The equation for the fitted line is given in Table $1\left(r^{2}=0.938, F=60.0, P=0.002\right)$

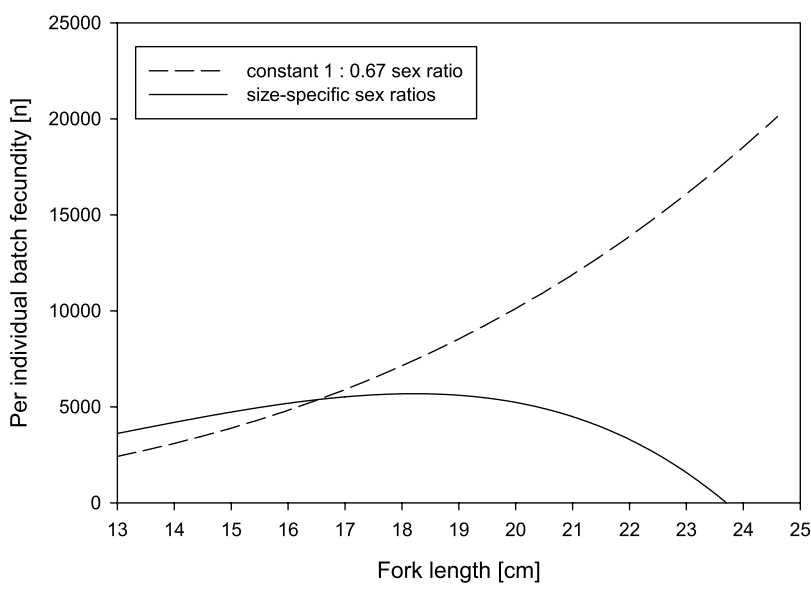

Fig. 10. The influence of size-specific sex ratios on population-level patterns of egg production: the overall sex-ratio (dashed curve) in Parupeneus barberinus makes it appear as though the largest individuals are responsible for the majority of egg production; however smaller individuals are responsible for the majority of egg production when size-specific sex ratios are considered (solid curve)

shows examples of immature and mature testes and ovaries. Ovaries of mature females contained several discrete stages of oocytes, indicating group-synchronous oocyte development (Wallace and Selman 1981). We therefore classified $K$. cinerascens as a batch spawner. Sexual differentiation occurs around $15 \mathrm{~cm}$ FL. The smallest male with spermiated testes was $18.1 \mathrm{~cm}$ FL. For males, the size at which $50 \%$ of individuals are mature $\left(L_{50}\right)$ is $20.1 \mathrm{~cm} \mathrm{FL} \mathrm{(Fig.} \mathrm{13).} \mathrm{All} \mathrm{males} \geq 22.4 \mathrm{~cm}$ were mature. Ovaries contained vitellogenic oocytes in females as small as $22.5 \mathrm{~cm}$ FL. We estimate female $L_{50}$ at $22.6 \mathrm{~cm}$ FL (Fig. 13). All females $\geq 30.7 \mathrm{~cm}$ FL were mature.

We did not see evidence of sex change in Kyphosus cinerascens. A $t$-test did not detect a significant sex-based difference in mean length $(t=-1.338, \mathrm{DF}=52, P=0.187)$. 
We did not see a central membrane-lined lumen in testes, nor did any gonad contain a mixture of ovarian and spermatogenic tissue. We classified $K$. cinerascens as a gonochore.

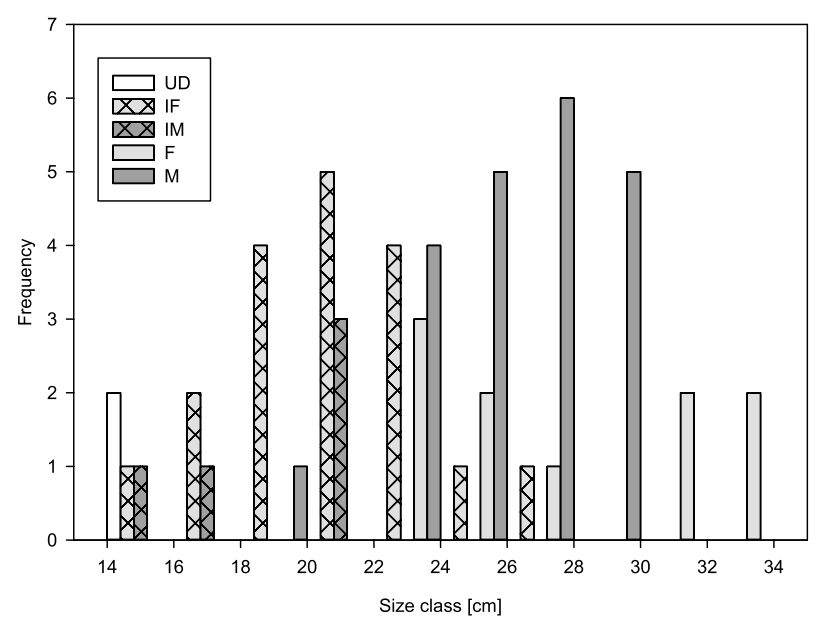

Fig. 11. Size-frequency plot of Kyphosus cinerascens specimens, with sex and maturity status determined by histological examination ofgonads; $\mathrm{UD}=$ undifferentiated individuals, IF = immature females, IM = immature males, $\mathrm{F}=$ mature females, $\mathrm{M}=$ mature males
Overall sex ratio in this Kyphosus cinerascens population was not significantly different from a 1 male : 1 female sex ratio (Table $1, \chi^{2}=0.074, \mathrm{DF}=1, P=$ $0.786)$. Considering only mature individuals, the observed sex ratio was male-biased $\left(\chi^{2}=3.903, \mathrm{DF}=1, P=0.048\right)$. We saw no evidence that the sex ratio of mature individuals varied predictably with length.

We had too few females with stage IV oocytes to construct a length-batch fecundity relation. However, batch fecundity ranged from 4607 and 11738 eggs in three females ranging from 23.0 to $32.0 \mathrm{~cm}$ FL.

Ctenochaetus striatus. ANCOVA did not detect a significant sex-based difference in length-weight relations $(F=0.46, \mathrm{DF}=1, P=0.502)$. Overall, total body weight $(W)$ in $g$ was an approximately cubic function of FL in $\mathrm{cm}$ (Table 1). The 95\% CI of regression parameters $a$ and $b$ were $0.0243-0.0472$ and $2.74-2.99$, respectively $\left(r^{2}=\right.$ $0.953, n=108$, FL range: $10.3-18.8, W$ range: $25-149)$.

We histologically examined gonads of 88 male and 64 female Ctenochaetus striatus. Figure 14 shows the sizefrequency distribution of each sex and maturity stage. Figure 15 shows examples of immature and mature testes and ovaries. Ovaries of mature females contained several discrete stages of oocytes, indicating group-synchronous oocyte development (Wallace and Selman 1981).
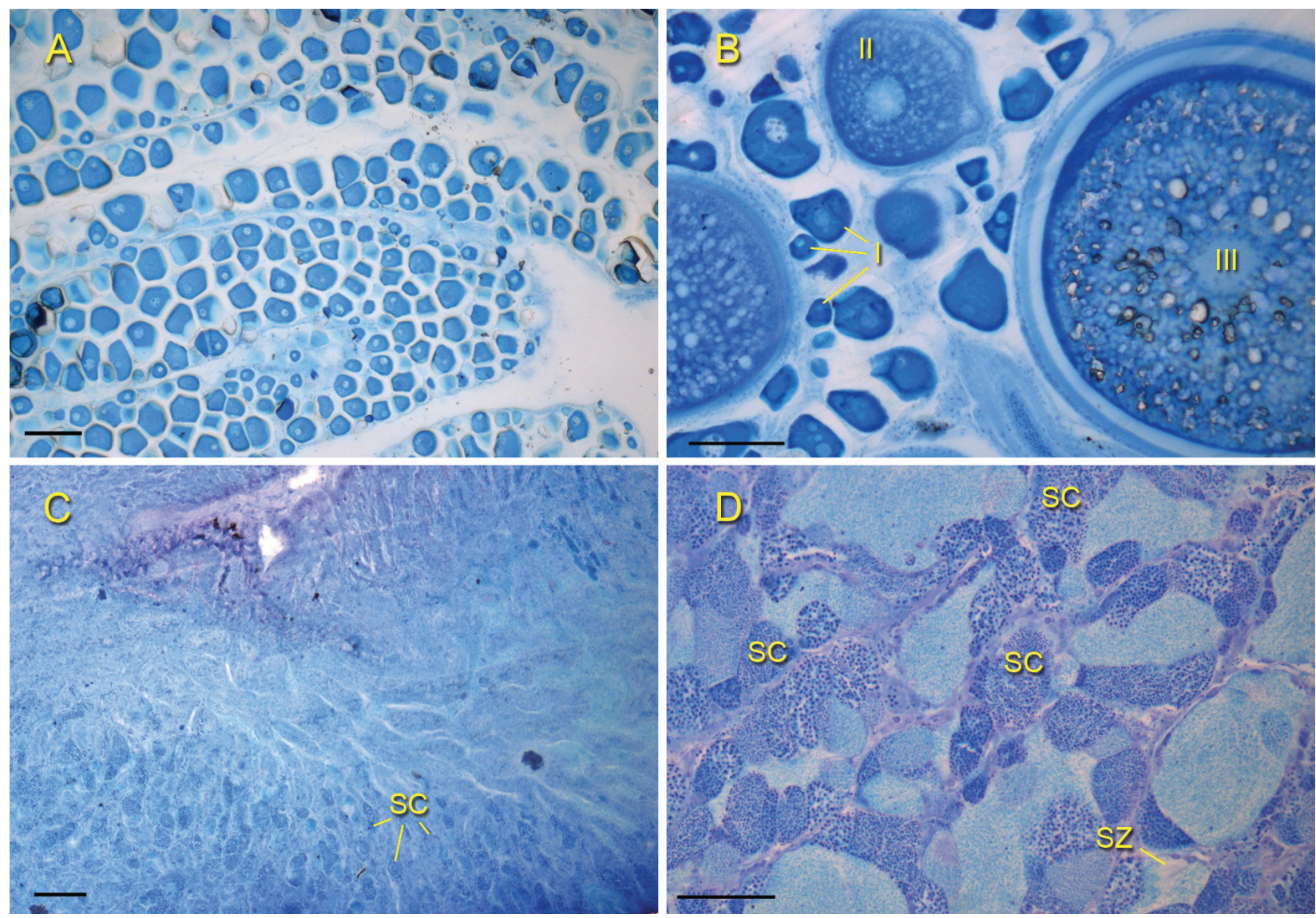

Fig. 12. Histological sections of gonads of blue sea chub, Kyphosus cinerascens, from Papua New Guinea: Ovary of immature female $(\mathbf{A})(20.4 \mathrm{~cm})$ containing only primary-growth oocytes; Ovary of mature female $(\mathbf{B})(32.0 \mathrm{~cm})$ containing primary-growth (I), cortical vesicle (II), and vitellogenic (III) oocytes; Testis from an immature male (C) $(20.4 \mathrm{~cm})$ containing spermatogenic cysts (SC); Testis of a mature male (D) $(26.0 \mathrm{~cm})$ with spermatogenic cysts (SC) and tailed spermatozoa (SZ); OL = ovarian lumen; scale bars $=100 \mu \mathrm{m}$ 


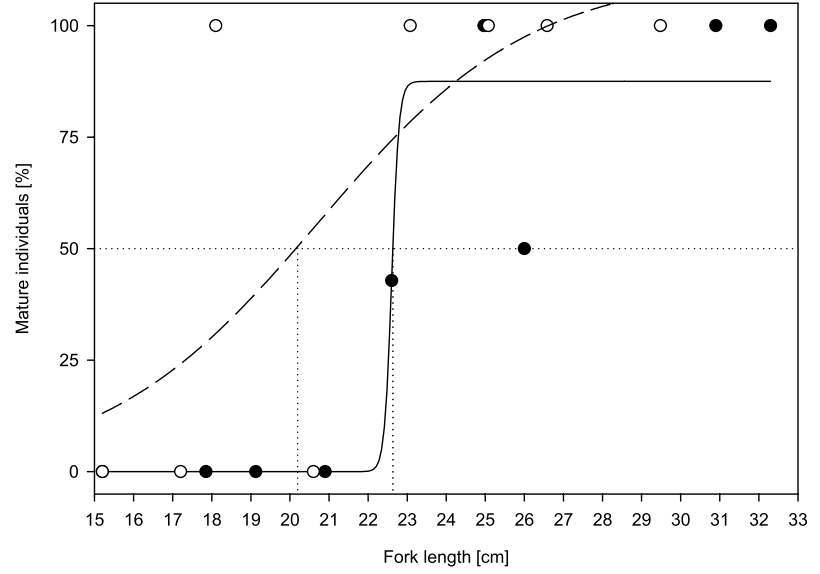

Fig. 13. Size-at-maturity $\left(L_{50}\right)$ for Kyphosus cinerascens from Papua New Guinea; Females are represented by closed circles and the solid line $\left(r^{2}=0.891, F=24.5, P\right.$ $=0.001)$, males are represented by open circles and the dashed line $\left(r^{2}=0.516, F=2.67, P=0.163\right)$

We therefore classified $C$. striatus as a batch spawner. Ovaries contained vitellogenic oocytes in females as small as $10.4 \mathrm{~cm} \mathrm{FL}$, and $85.9 \%$ of the females we examined were mature. The smallest male with spermiated testes

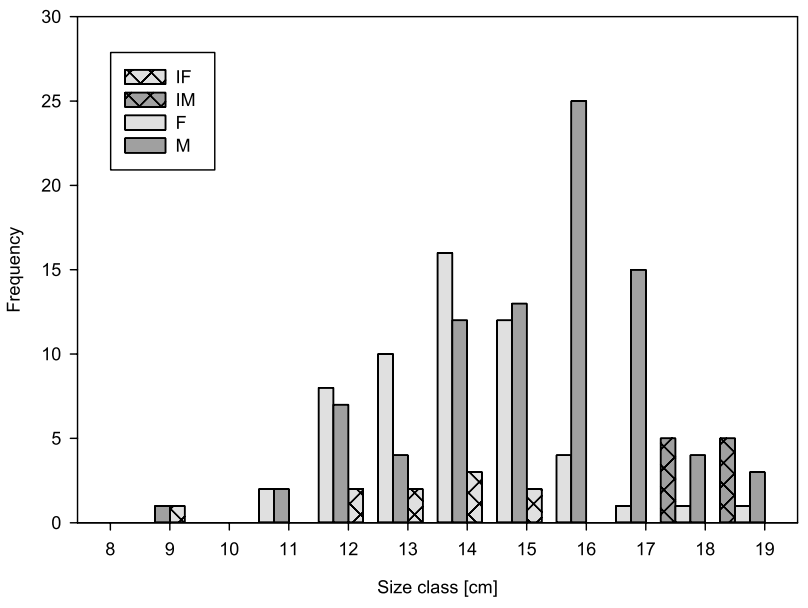

Fig. 14. Size-frequency plot of Ctenochaetus striatus specimens, with sex and maturity status determined by histological examination of gonads; IF = immature females, $\mathrm{IM}=$ immature males, $\mathrm{F}=$ mature females, $\mathrm{M}$ $=$ mature males
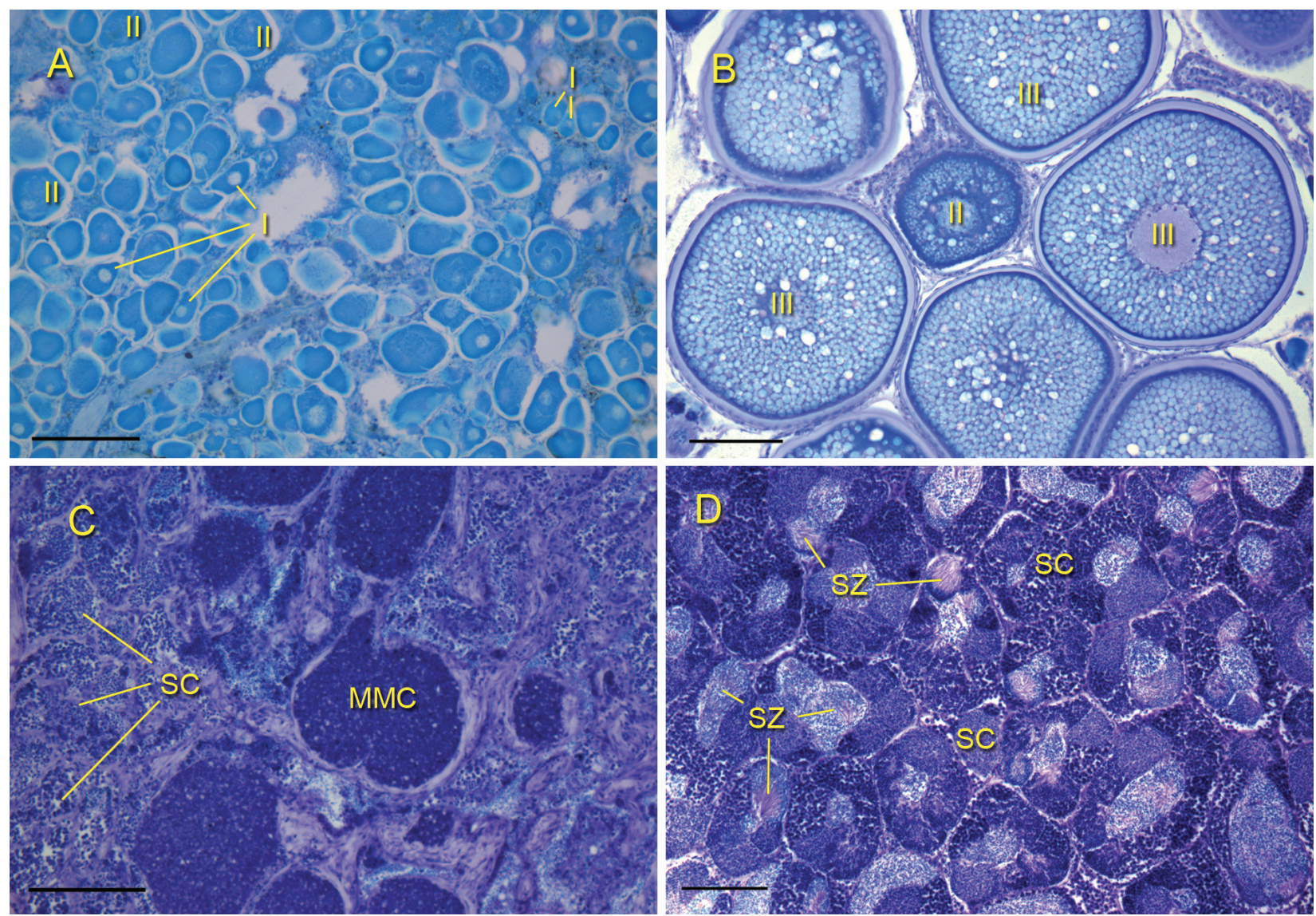

Fig. 15. Histological sections of gonads of striated surgeonfish, Ctenochaetus striatus, from Papua New Guinea: Ovary of immature female (A) $(14.9 \mathrm{~cm})$ containing primary-growth (I) and cortical vesicle (II) oocytes; Ovary of mature female (B) $(14.9 \mathrm{~cm})$ containing cortical vesicle (II) and vitellogenic (III) oocytes; Testis from an immature male (C) $(17.4 \mathrm{~cm})$ containing spermatogenic cysts (SC) and probable melano-macrophage centres (MMC); Testis of a mature male (D) $(16.4 \mathrm{~cm})$ with spermatogenic cysts $(\mathrm{SC})$ and tailed spermatozoa (SZ); scale bars $=100 \mu \mathrm{m}$ 
We saw a sex-based bimodal size distribution in Ctenochaetus striatus. A $t$-test indicated mean length of males was significantly greater than that of females $(t=$ $-4.429, \mathrm{DF}=148, P<0.001)$. There was no other evidence of sex change; we did not see a central membrane-lined lumen in testes, nor did any gonad contain a mixture of ovarian and spermatogenic tissue. We classified $C$. striatus as a gonochore.

Overall sex ratio in this Ctenochaetus striatus population was not significantly different from 1 male : 1 female (Table $1, \chi^{2}=3.227, \mathrm{DF}=1, P=0.0724$ ). Considering only mature individuals, the observed sex ratio was male-biased $\left(\chi^{2}=7.111, \mathrm{DF}=1, P=0.008\right)$. Additionally, we saw size-specific sex ratios in the mature size classes; the sex ratio of mature individuals varied predictably with length (Fig. 16). Smaller size classes were male-biased, switched to a female-biased state as length increased, and the largest size classes were malebiased. An equation describing the percent of mature females $(\%$ ) $)$, throughout the size range of mature specimens (Table $1, r^{2}=0.80$ ), predicts that the population was female biased between 11.0 and $14.0 \mathrm{~cm}$ FL.

We had too few females with stage IV oocytes to construct a length-batch fecundity relation. However, batch fecundity ranged from 7904 and 37975 eggs in two females ranging from 15.1 to $18.7 \mathrm{~cm}$ FL.

Balistapus undulatus. ANCOVA detected a significant sex-based difference in length-weight relations $(F=4.98$, $\mathrm{DF}=1, P=0.029)$. Overall and sex-based LWRs are presented in Table 1. Overall, total body weight $(W)$ in $g$ was an approximately cubic function of TL in $\mathrm{cm}$. 95\% CI of regression parameters $a$ and $b$ were $0.0224-0.0284$ and 2.98-3.07, respectively $\left(r^{2}=0.990, n=177\right.$, FL range: 4.1-21.9, $W$ range: $1.4-250)$. Males tended to weigh more per unit length than females. For females, the 95\% CI of regression parameters $a$ and $b$ were $0.0217-0.0552$ and 2.73-3.09, respectively $\left(r^{2}=0.958, n=48\right.$, FL range: 8.4-16.0, $W$ range: $17-105)$. For males, the $95 \%$ CI of

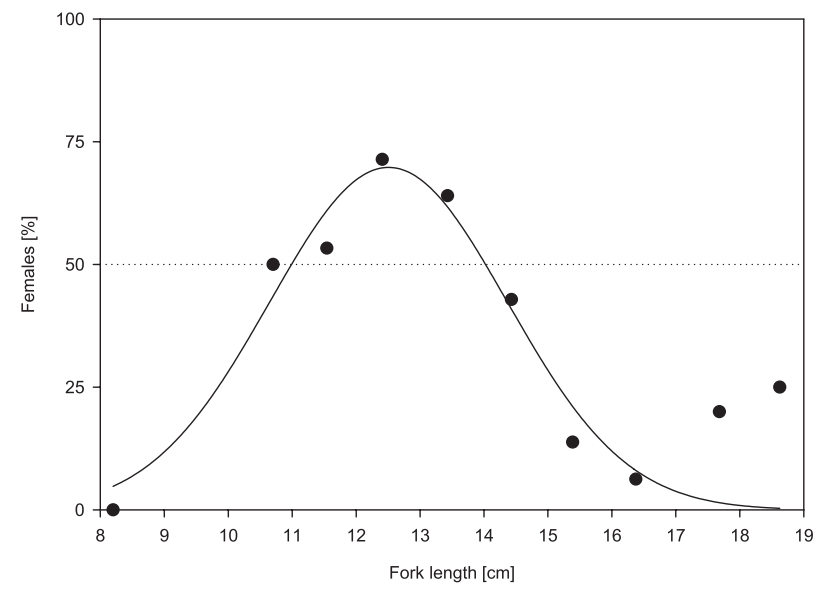

Fig. 16. Percentage of mature females, relative to all mature individuals, versus length for Ctenochaetus striatus from Papua New Guinea. The equation for the fitted curve is given in Table $1\left(r^{2}=0.796, F=13.9, P\right.$ $=0.004$ ) regression parameters $a$ and $b$ were $0.0400-0.109$ and 2.52-2.87, respectively $\left(r^{2}=0.982, n=21\right.$, FL range: 10.8-21.9, $W$ range: $36-250)$.

We histologically examined gonads of 12 undifferentiated, 110 female, and 45 male Balistapus undulatus. Figure 17 shows the size-frequency distribution of each sex and maturity stage. Figure 18 shows examples of immature and mature testes and ovaries. Ovaries of mature females contained several discrete stages of oocytes, indicating group-synchronous oocyte development (Wallace and Selman 1981). We therefore classified B. undulatus as a batch spawner. Ovaries contained vitellogenic oocytes in females as small as $8.4 \mathrm{~cm}$ TL. We estimate female $L_{50}$ at $15.7 \mathrm{~cm}$ TL (Fig. 19). The smallest male with spermiated testes was 12.9 $\mathrm{cm}$ TL. Because the percentage of mature individuals fell below 50\% in all size classes (Fig. 19), we could not reliably estimate male $L_{50}$.

We saw a sex-based bimodal size distribution in Balistapus undulatus. A $t$-test indicated mean length of males was significantly greater than that of females $(t=$ $-6.359, \mathrm{DF}=58, P<0.001)$. There was no other evidence of sex change in $B$. undulatus. We did not see a central membrane-lined lumen in testes, nor did any gonad contain a mixture of ovarian and spermatogenic tissue. We classified $B$. undulatus as a gonochore.

Overall sex ratio in this Balistapus undulatus population was female-biased (Table 1, $\chi^{2}=27.258, \mathrm{DF}=1, P<0.001$ ). Considering only mature individuals, the observed sex ratio was also female-biased $\left(\chi^{2}=10.246, \mathrm{DF}=1, P=0.001\right)$. However we did see size-specific sex ratios in the mature size classes; the sex ratio of mature individuals varied predictably with length (Fig. 20). An equation describing the percent of mature females $(\%$ \% $)$, throughout the size range of mature specimens (Table $1, r^{2}=0.978$ ), predicts that the population was male biased at body lengths $>16.6$ $\mathrm{cm}$ TL. The percentage of females dropped to $6.8 \%$ at maximum observed size of $20.2 \mathrm{~cm}$ TL.

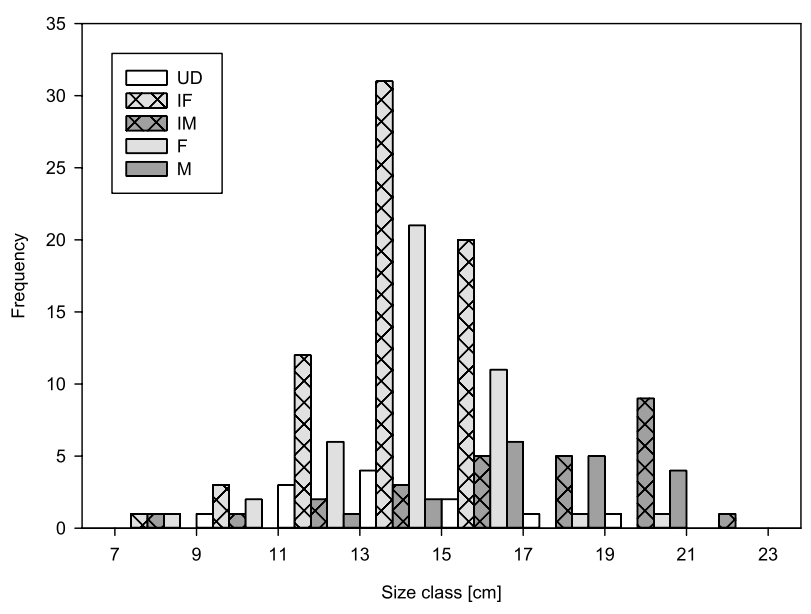

Fig. 17. Size-frequency plot of Balistapus undulatus specimens, with sex and maturity status determined by histological examination of gonads; UD = undifferentiated individuals, $\mathrm{IF}=$ immature females, $\mathrm{IM}=$ immature males, $\mathrm{F}=$ mature females, $\mathrm{M}=$ mature males 
Linear regression analysis of log-transformed data produced a non-significant $(F=2.520, n=4, P=0.253)$, poorly descriptive $\left(r^{2}=0.558\right)$ length-batch fecundity relation. Results suggest that batch fecundity is an exponential $(b>6)$ function of total length for females $13.2-16.2 \mathrm{~cm}$ (Table 1).
Figure 21 shows the relation between length and expected individual batch fecundity with observed overall sex ratios and with observed size-specific sex ratios. With an assumed constant sex ratio, expected per-individual egg production is greatest at maximum size. When size-
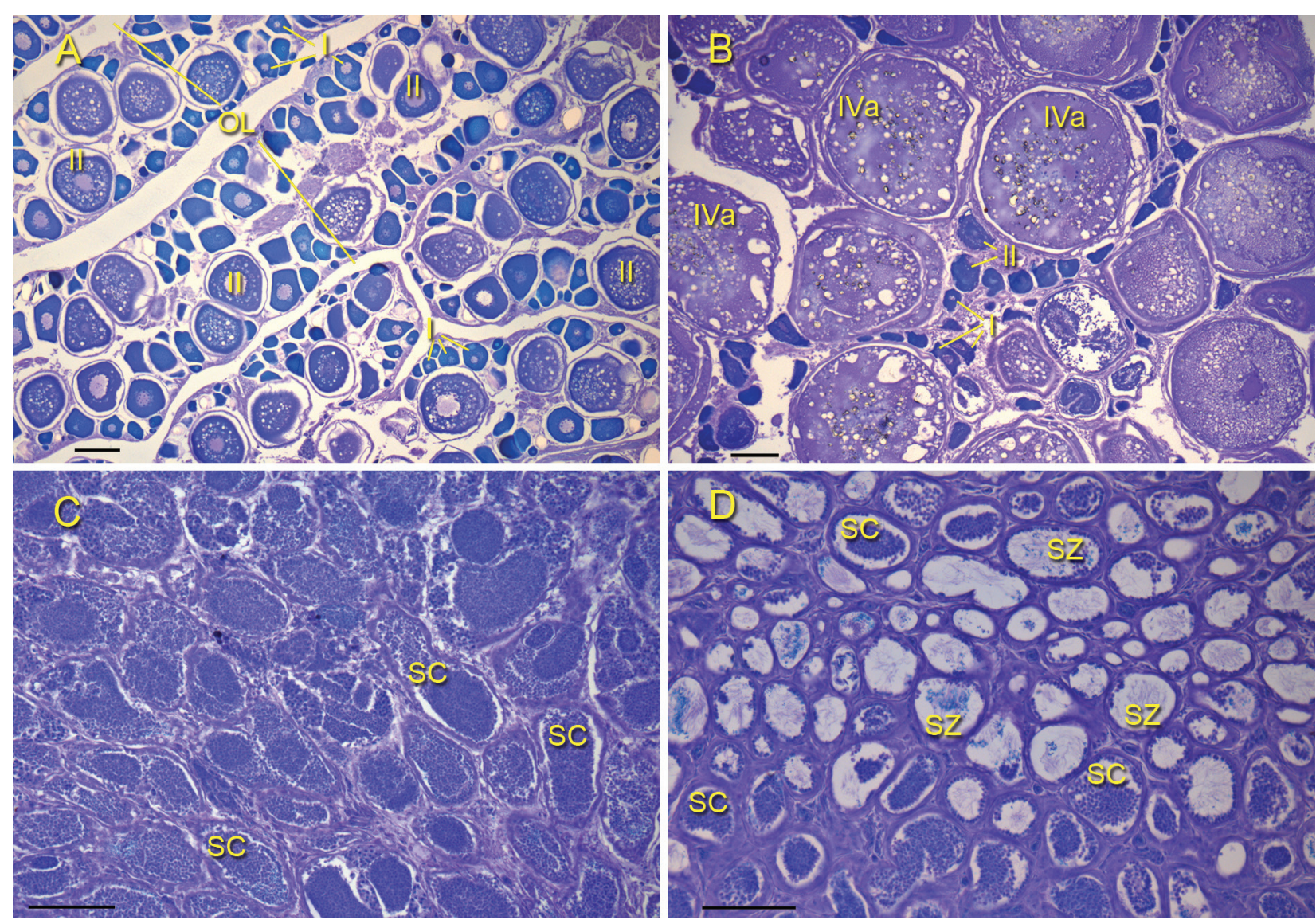

Fig. 18. Histological sections of gonads of orange-lined triggerfish, Balistapus undulatus, from Papua New Guinea: Ovary of immature female (A) $(16.5 \mathrm{~cm})$ containing primary-growth (I) and cortical vesicle (II) oocytes; Ovary of mature female (B) $(18.2 \mathrm{~cm})$ containing primary-growth (I), cortical vesicle (II), and final maturation (IVa) oocytes; Testis from an immature male (C) $(20.4 \mathrm{~cm})$ containing spermatogenic cysts (SC); Testis of a mature male (D) (16.8 $\mathrm{cm}$ ) with spermatogenic cysts (SC) and tailed spermatozoa (SZ); OL = ovarian lumen; scale bars $=100 \mu \mathrm{m}$

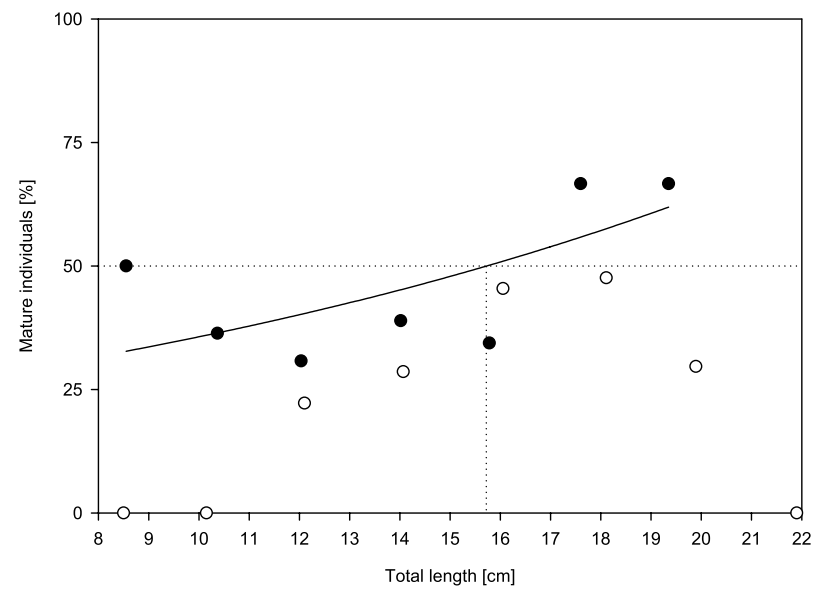

Fig. 19. Size-at-maturity $\left(L_{50}\right)$ for Balistapus undulatus from Papua New Guinea; Females are represented by closed circles and the solid line $\left(r^{2}=0.409, F=1.38, P\right.$ $=0.394)$, males are represented by open circles

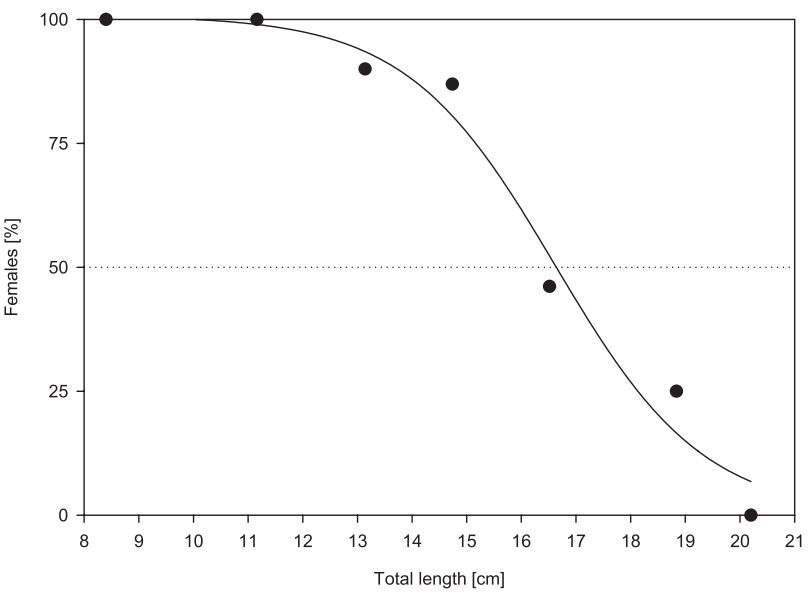

Fig. 20. Percentage of mature females, relative to all mature individuals, versus length for Balistapus undulatus from Papua New Guinea; The equation for the fitted curve is given in Table $1\left(r^{2}=0.978, F=90.4, P<0.001\right)$ 
specific sex ratios are considered, the small chance of an individual being a female eventually overwhelms increases in batch fecundity such that expected egg production per individual peaks at $16.6 \mathrm{~cm} \mathrm{TL}$, well below maximum observed length (Fig. 21, solid curve). Failing to account for size-specific sex ratios at the largest observed specimen size led to a 427655 -egg overestimate in expected individual batch fecundity.

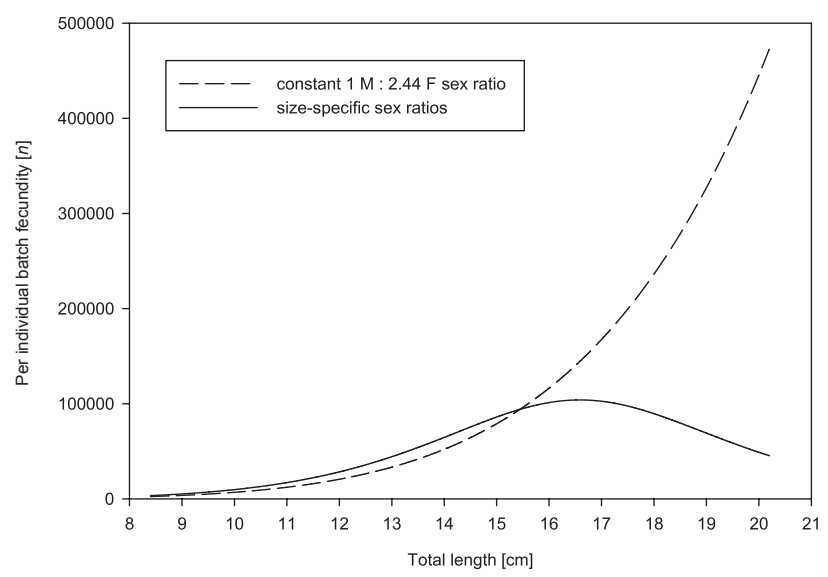

Fig. 21. The influence of size-specific sex ratios on population-level patterns of egg production: the overall sex-ratio (dashed curve) in Balistapus undulatus makes it appear as though the largest individuals are responsible for the majority of egg production, however smaller individuals are responsible for the majority of egg production when size-specific sex ratios are considered (solid curve)

\section{DISCUSSION}

Above, we presented a suite of reproductive parameters for five exploited reef-fish species, generated using Jungle Histology methods. These methods allow reproductive information to be generated quickly and at low cost, thus eliminating the perceived impediments to broad-scale reproductive analysis of Pacific coral-reef fishes. However, in the interest of rapidly increasing the amount of available reproductive information, Jungle Histology uses only one gonad subsample from the minimum number of specimens necessary to generate estimates of reproductive parameters. Therefore, results should be viewed as preliminary (Longenecker et al. 2014).

Despite the preliminary nature of these results, we think they are a useful contribution to the currently insufficient body of knowledge about reproduction in Pacific coral-reef fishes. Because microscopic examination of gametes yields a more-reliable evaluation of individual reproductive status than gross (i.e., macroscopic) or data-deficient methods (e.g., Froese and Binohlan 2000), we suggest that results of histological analysis are particularly necessary when evaluating the sustainability of reef-fishing practices. This is most convincingly demonstrated with our results for Nemipterus isacanthus, which were generated by the subset of authors who developed the Jungle Histology methods, and were the most experienced at macroscopic evaluation of maturity. Our macroscopic evaluations were incorrect (wrong sex and/or reproductive status) for $62.6 \%$ of $N$. isacanthus specimens examined. Similar differences between histological and macroscopic results have been reported previously (Vitale et al. 2006, Grandcourt et al. 2011, Longenecker et al. 2013a, 2013c). Although Mackie and Lewis (2001) report that accuracy of macroscopic staging improves as personnel gain experience, they also state that misclassification rate exceeds $40 \%$ for many gonad stages, even when workers are experienced. In the case of $N$. isacanthus, our macroscopic misclassification errors would have led to $L_{50}$ estimates of $18.9 \mathrm{~cm}$ FL for males and 20.9 $\mathrm{cm}$ FL for females. On the basis of our largest specimen (24.9 $\mathrm{cm} \mathrm{FL})$, the empirical equations of Froese and Binohlan (2000) predict that males mature at $14.5 \mathrm{~cm}$ FL and females mature at $16.8 \mathrm{~cm} \mathrm{FL}$. The results of our macroscopic analysis would indicate that $92.5 \%$ of the $N$. isacanthus catch we examined had not attained the size at female maturity, whereas the data-deficient approach (Froese and Binohlan 2000) would indicate that 75.7\% of the catch had not attained female size at maturity. Thus, estimating $L_{50}$ based on macroscopic analysis or the Froese and Binohlan equation would suggest that this $N$. isacanthus population is being unsustainably harvested (Froese 2004). However, histological analysis showed that only $21.5 \%$ of the catch was immature, and suggested that $100 \%$ of the catch was larger than female $L_{50}$. Thus, the results of our (presumably more-reliable) histological analysis suggest that this $N$. isacanthus population is being sustainably harvested.

These methods-based differences in the interpretation of fishing sustainability could have profound impacts on management strategies. The macroscopic and datadeficient approaches could lead fishery managers to impose fishing restrictions on the Nemipterus isacanthus population we studied, whereas the histological approach suggests that no management actions are necessary. Thus, the histological approach can help avoid the expense of unnecessary management actions that would make it more difficult for subsistence fishers to obtain food. Conversely, because of their increased accuracy, histological analyses may also enable managers to better identify stocks that are overexploited and institute effective management before the population declines to critical levels. For example, Vitale et al. (2006) found that macroscopic analysis of Gadus morhua stocks overestimated spawning stock by up to $35 \%$, relative to histological analysis of gonads from the same population. For subsistence fishing communities in developing nations such as Papua New Guinea, the need to avoid unnecessary or inaccurate management action cannot be overstated.

Although several authors have shown that histological analysis is inherently more detailed/informative than macroscopic analyses (Mackie and Lewis 2001, Vitale et al. 2006), many continue to rely on macroscopic and gravimetric (gonadosomatic index) analyses because they 
believe histological analysis to be too costly and labor intensive (Klibansky and Scharf 2015). We disagree. Using the simplified methods we have described (Longenecker et al. 2013a, 2013b, 2013c, 2014, 2016) histological analysis is fast and economical. Longenecker et al. (2013a) estimated the cost of consumable supplies at $\$ 1.45$ US per specimen. More recent record keeping demonstrates that total processing time is $30 \mathrm{~min}$ per specimen, including: whole-specimen length and weight measurements; excising and weighing whole gonads; and weighing, fixing, trimming, infiltrating, embedding, sectioning, staining, and microscopically evaluating gonad subsamples (note that these steps include the work necessary for both macroscopic and gravimetric analyses). The histological analysis portion requires only 17 minutes more, per specimen, than would be needed for macroscopic evaluation. When weighed against the possibility of instituting flawed management based on inaccurate macroscopic or data-deficient methods, we suggest the extra time and monetary investments are easily justified.

Another benefit of our rapid approach to reproductive analyses is the ability to identify emergent patterns. For instance, females of four of the five species in this study become less abundant as size class increases (Nemipterus isacanthus, Parupeneus barberinus, Ctenochaetus striatus, Balistapus undulatus). Similar patterns have been reported for confamilial species (Young and Martin 1985, Russell 1990, Lau and Sadovy 2001, Puentes Granada et al. 2004, Mant et al. 2006, Longenecker and Langston 2008, Langston et al. 2009, Boaden and Kingsford 2013, Amira et al. 2016, Pyle et al. 2016, Longenecker et al. 2016) and members of other families (Longenecker et al. 2014, 2016) subject to rapid reproductive analyses.

Although the pattern has been reported elsewhere, the impact of these size-specific sex ratios on which size classes are overwhelmingly responsible for populationlevel egg production is currently under-recognized (but see Longenecker et al. 2014, 2016). It has long been a common assumption that large fish are disproportionately responsible for population-level reproductive output because large females produce many more eggs than small females (see Roberts and Polunin 1993, Allison et al. 1998, Halpern 2003, Froese 2004, Birkeland and Dayton 2005, Sale et al. 2005). However, the assumption may not hold if females are rare in the largest size classes, and cannot hold if females are absent. Thus, the curves in Figs. 10 and 21 show the relation between length and expected individual batch fecundity with observed overall sex ratios and with observed sizespecific sex ratios. Expected individual batch fecundity at a given length is the product of the result of the lengthfecundity relation and the likelihood that a randomly chosen individual (at the given length) is a female. Thus the curves represent the mean batch fecundity of any individual at a given length and not just females. For both examples, when size-specific sex ratios are considered, the decreasing likelihood that an individual is female eventually overwhelms increases in batch fecundity such that mean egg production per individual peaks well below maximum observed length (Figs. 10 and 21, solid curves).

The consequence of these patterns cannot be overstated. Assuming spawning frequency remains the same over the lifespan of an individual, considering size-specific sex ratios predicts that for Parupeneus barberinus, $50 \%$ of expected lifetime egg production occurs by the time an individual attains $17.6 \mathrm{~cm}$ FL, whereas if sex ratios are assumed to be constant, an individual would have to be 24 percentage points larger. More importantly, assuming that sex ratios are constant suggests that the largest individuals produce 22100 eggs per spawning event, whereas when size-specific sex ratios are considered, none of the largest individuals are females and egg production would be expected to be zero. In fact, egg production would have stopped in all individuals $1.5 \mathrm{~cm}$ shorter than maximum observed specimen size. Similar results were obtained for Balistapus undulatus. When considering size-specific sex ratios, 50\% of expected lifetime egg production occurs by the time an individual attains $16.2 \mathrm{~cm}$ TL, whereas an individual would have to be 13 percentage points larger to achieve the same reproductive output if sex ratios are assumed to be constant. Furthermore, failing to account for sizespecific sex ratios at the largest observed specimen size led to a 10.4 X overestimate (473 003 vs. 45348 eggs) in expected individual batch fecundity. The implications of size-specific sex ratios for fishery conservation and management are that, when females are rare or absent in the largest size classes, fishing at or near the maximal size for a species may have little impact on the overall reproductive output for the population. Furthermore, imposing slot limits that protect the largest size classes may actually redirect fishing pressure on the size classes of female fish that are collectively responsible for the majority of population-level reproductive output.

\section{ACKNOWLEDGEMENTS}

The Jungle Histology workshop was funded by a grant from NOAA's Saltonstall-Kennedy Grant Program pursuant to Project Number NA14NMF4270057. A private foundation, wishing to remain anonymous, provided financial support for work at KWMA. The Nago Island Mariculture and Research Facility provided in-kind support. We thank the fishers of Kavieng and the Kamiali Wildlife Management Area for collecting specimens (national-level approval included in wildlife export permit \#015100). Shelley James provided logistical support, Sven Frijlink provided vessel support in Kavieng, and Bulisa Iova provided invaluable help obtaining an export permit. This is contribution 2017-001 of the Pacific Biological Survey, SOEST contribution 10021, and HIMB contribution 1687.

\section{REFERENCES}

Agger P., Bagge O., Hansen O., Hoffman E., Holder M.J., Kesteven G.L., Knudsen H., Raitt D.F.S., Saville A., Williams T. 1974. Manual of fisheries 
science. Part 2. methods of resource investigation and their application. FAO Fisheries Technical Paper T115 (Rev. 1). FAO, Rome, Italy.

Allison G.W., Lubchenco J., Carr M.H. 1998. Marine reserves are necessary but not sufficient for marine conservation. Ecological Applications 8 (Suppl. 1): S79-S92.

DOI: 10.1890/1051-0761(1998)8[S79:MRANBN]2.0.CO;2

Amira F.S., Rahman M.M., Kamaruzzaman B.Y., Jalal K.C.A., Hossain M.Y., Khan N.S. 2016. Relative abundance and growth of male and female Nemipterus furcosus population. Sains Malaysiana 45 (1): 79-86.

Birkeland C., Dayton P.K. 2005. The importance in fishery management of leaving the big ones. Trends in Ecology and Evolution 20 (7): 356-358.

DOI: $10.1016 /$ j.tree.2005.03.015

Boaden A.E., Kingsford M.J. 2013. Distributions and habitat associations of the bridled monocle bream Scolopis bilineatus (Nemipteridae): A demographic approach. Journal of Fish Biology 83 (3): 618-641. DOI: $\underline{10.1111 / \mathrm{jfb} .12200}$

Crawford K., Harper S., Zeller D. 2011. Reconstruction of marine fisheries catches for Tuvalu (1950-2009). Fisheries Centre Research Reports 19 (4): 131-143.

Dalzell P. 1998. The role of archaeological and culturalhistorical records in long-range coastal fisheries resources management strategies and policies in the Pacific Islands. Ocean and Coastal Management 40 (2-3): 237-252.

DOI: $10.1016 / \mathrm{S} 0964-5691(98) 00043-\mathrm{X}$

DeMartini E.E., Howard K.G. 2016. Comparisons of body sizes at sexual maturity and at sex change in the parrotfishes of Hawaii: Input needed for management regulations and stock assessments. Journal of Fish Biology 88 (2): 523-541.

DOI: $10.1111 / \mathrm{jfb} .12831$

DeMartini E.E., Langston R.C., Eble J.A. 2014. Spawning seasonality and body sizes at sexual maturity in the bluespine unicornfish, Naso unicornis (Acanthuridae). Ichthyological Research 61 (3): 243-251.

DOI: $10.1007 / \mathrm{s} 10228-014-0393-\mathrm{Z}$

Feary D.A., Cinner J.E., Graham N.A.J., JanuchowskiHartley F.A. 2011. Effects of customary marine closures on fish behavior, spear-fishing success, and underwater visual surveys. Conservation Biology 25 (2): 341-349.

DOI: $10.1111 / \mathrm{j} .1523-1739.2010 .01613 . \mathrm{x}$

Friedlander A.M., DeMartini E.E. 2002. Contrasts in density, size, and biomass of reef fishes between the northwestern and the main Hawaiian islands: The effects of fishing down apex predators. Marine Ecology Progress Series 230: 253-264. DOI: $10.3354 /$ meps 230253

Froese R. 2004. Keep it simple: Three indicators to deal with overfishing. Fish and Fisheries 5 (1): 86-91. DOI: $10.1111 /$ j.1467-2979.2004.00144.X

Froese R., Binohlan C. 2000. Empirical relationships to estimate asymptotic length, length at first maturity and length at maximum yield per recruit in fishes, with a simple method to evaluate length frequency data. Journal of Fish Biology 56 (4): 758-773.

DOI: $\underline{10.1111 / j .1095-8649.2000 . t b 00870 . x}$

Froese R., Pauly D. (eds.) 2016. FishBase. [Version 1/2016] www.fishbase.org

Froese R., Tsikliras A.C., Stergiou K.I. 2011. Editorial note on weight-length relations of fishes. Acta Ichthyologica et Piscatoria 41 (4): 261-263.

DOI: $10.3750 / A I P 2011.41 .4 .01$

Grandcourt E.M. 2002. Demographic characteristics of a selection of exploited reef fish from the Seychelles: Preliminary study. Marine and Freshwater Research 53 (2): 123-130.

DOI: $10.1071 / \mathrm{MF} 01123$

Grandcourt E.M., Al Abdessalaam T.Z., Al Shamsi A.T., Francis F. 2006. Biology and assessment of the painted sweetlips (Diagramma pictum (Thunberg, 1792)) and the spangled emperor (Lethrinus nebulosus (Forsskål)) in the southern Arabian Gulf. Fishery Bulletin 104 (1): 75-88.

Grandcourt E.M., Al Abdessalaam T.Z., Francis F., Al Shamsi A.T. 2011. Reproductive biology and implications for management of the painted sweetlips Diagramma pictum in the southern Arabian Gulf. Journal of Fish Biology 79 (3): 615-632. DOI: $10.1111 / \mathrm{j} .1095-8649.2011 .03044 . \mathrm{x}$

Halpern B.S. 2003. The impact of marine reserves: Do reserves work and does reserve size matter? Ecological Applications 13 (Suppl. 1): S117-S137. DOI: $10.1890 / 1051-0761(2003) 013$ [0117:TIOMRD]2.0.CO;2

Houk P., Rhodes K., Cuetos-Bueno J., Lindfield S., Fread V., McIlwain J.L. 2012. Commercial coralreef fisheries across Micronesia: A need for improving management. Coral Reefs 31 (1): 13-26. DOI: $10.1007 / \mathrm{s} 00338-011-0826-3$

Johannes R.E. 1998. The case for data-less marine resource management: Examples from tropical nearshore finfisheries. Trends in Ecology and Evolution 13 (6): 243-246. DOI: $10.1016 / \mathrm{S} 0169-5347(98) 01384-6$

Klibansky N., Scharf F.S. 2015. Success and failure assessing gonad maturity in sequentially hermaphroditic fishes: Comparisons between macroscopic and microscopic methods. Journal of Fish Biology 87 (4): 930-957. DOI: $10.1111 / \mathrm{jfb} .12765$

Langston R., Longenecker K., Claisse H. 2009. Growth, mortality and reproduction of kole, Ctenochaetus strigosus. Final report prepared for Fisheries Local Action Strategy, Division of Aquatic Resources, 1151 Punchbowl St., Room 330, Honolulu, Hawai'i. Hawaii Biological Survey Contribution 2009-005.

Lau P.P.F., Sadovy Y. 2001. Gonad structure and sexual pattern in two threadfin breams and possible function of the dorsal accessory duct. Journal of Fish Biology 58 (5): 1438-1453. DOI: $10.1111 /$ j.1095-8649.2001.tb02298.x

Longenecker K., Giamsa H. 2016. First report of teardrop threadfin bream, Nemipterus isacanthus 
(Actinopterygii: Perciformes: Nemipteridae), from the Solomon Sea, Papua New Guinea. Acta Ichthyologica et Piscatoria 46 (2): 119-121.

DOI: 10.3750/AIP2016.46.2.08

Longenecker K., Langston R. 2008. A rapid, low-cost technique for describing the population structure of reef fishes. Final report prepared for Hawaii Coral Reef Initiative-Research Program, 2424 Maile Way, Saunders Hall, 718 Honolulu, HI 96822. Hawaii Biological Survey Contribution No. 2008-002. Bishop Museum, Honolulu, HI, USA.

Longenecker K., Langston R. 2016. Rapid reproductive analysis of four heavily exploited reef fishes from Pohnpei State, Federated States of Micronesia. Bishop Museum Technical Report No. 68.

DOI: $10.13140 /$ RG.2.2.26726.83525

Longenecker K., Langston R., Bolick H. 2013a. Rapid reproductive analysis and length-dependent relationships of Lutjanus biguttatus (Perciformes: Lutjanidae) from Papua New Guinea. Pacific Science 67 (2): 295-301.

DOI: $10.2984 / 67.2 .11$

Longenecker K., Langston R., Bolick H., Kondio U. 2011. Reproduction, catch, and size structure of exploited reef-fishes at Kamiali Wildlife Management Area, Papua New Guinea. Bishop Museum Technical Report No. 57.

DOI: 10.13140/RG.2.1.5071.7683

Longenecker K., Langston R., Bolick H., Kondio U. 2013b. Size and reproduction of exploited reef fishes at Kamiali Wildlife Management Area, Papua New Guinea. Bishop Museum Technical Report No. 62.

DOI: 10.13140/RG.2.1.2712.4722

Longenecker K., Langston R., Bolick H., Kondio U. 2013c. Rapid reproductive analysis and lengthweight relation for blacktail snapper, Lutjanus fulvus (Actinopterygii: Perciformes: Lutjanidae), from a remote village in Papua New Guinea. Acta Ichthyologica et Piscatoria 43 (1): 51-55.

DOI: $10.3750 / A I P 2013.43 .1 .07$

Longenecker K., Langston R., Bolick H., Kondio U. 2014. Rapid reproductive analysis and lengthweight relation for red-bellied fusilier, Caesio cuning, and longfin emperor, Lethrinus erythropterus (Actinopterygii: Perciformes: Caesiondiae and Lethrinidae) from a remote village in Papua New Guinea. Acta Ichthyologica et Piscatoria 44 (1): 75-84. DOI: $\underline{\text { 10.3750/AIP2014.44.1.10 }}$

Longenecker K., Langston R., Crane M. 2017. Hermaphroditism in the dash-and-dot goatfish, Parupeneus barberinus. Journal of Fish Biology 90 (3): 1149-1152.

DOI: $10.1111 / \mathrm{jfb} .13254$

Longenecker K., Langston R., Kondio U., Bolick H., Mulrooney M. 2016. Rapid reproductive analysis and length-weight relations of three reef fishes (Actinopterygii: Perciformes and Tetraodontiformes) from a remote site in Papua New Guinea. Acta Ichthyologica et Piscatoria 46 (3): 263-270.

DOI: $\underline{10.3750 / A I P 2016.46 .3 .11}$

Mant J.C., Moran M.J., Newman S.J., Hesp S.A., Hall N.G., Potter I.P. 2006. Biological characteristics of western butterfish (Pentapodus vitta), an abundant bycatch species of prawn trawling and recreational fishing in a large subtropical embayment. Fishery Bulletin 104 (4): 512-520.

Mackie M., Lewis P. 2001. Assessment of gonad staging systems and other methods used in the study of the reproductive biology of narrow-barred Spanish mackerel, Scomberomorus commerson, in Western Australia. Fisheries Research Report No. 136. Department of Fisheries, Government of Western Australia, Perth, WA, Australia.

Matsuura K. 2001. Balistidae. Triggerfishes. Pp. 39113928. In: Carpenter K.E., Niem V. (eds.) FAO species identification guide for fishery purposes. The living marine resources of the Western Central Pacific. Vol. 6. Bony fishes part 4 (Labridae to Latimeriidae), estuarine crocodiles, sea turtles, sea snakes and marine mammals. FAO, Rome.

McClanahan T.R., Hicks C.C., Darling E.S. 2008. Malthusian overfishing and efforts to overcome it on Kenyan coral reefs. Ecological Applications 18 (6): 1516-1529. DOI: 10.1890/07-0876.1

McClanahan T.R., Muthiga N.A., Kamukuru A.T., Machano H., Kiambo R.W. 1999. The effects of marine parks and fishing on coral reefs of northern Tanzania. Biological Conservation 89 (2): 161-182. DOI: 10.1016/S0006-3207(98)00123-2

Nagahama Y. 1983. The functional morphology of teleost gonads. Pp. 223-276. In: Hoar W.S., Randall D.J, Donaldson E.M. (eds.) Fish physiology. Vol. IX. Reproduction. Part A. Endocrine tissues and hormones. Academic Press, New York, NY, USA.

Ochavillo D., Tofaeono S., Sabater M., Trip E.L. 2011. Population structure of Ctenochaetus striatus (Acanthuridae) in Tutuila, American Samoa: The use of size-at-age data in multi-scale population size surveys. Fisheries Research 107 (1-3): 14-21.

DOI: 10.1016/j.fishres.2010.10.001

Ohta I., Ebisawa A. 2015. Reproductive biology and spawning aggregation fishing of the white-streaked grouper, Epinephelus ongus, associated with seasonal and lunar cycles. Environmental Biology of Fishes 98 (6): 1555-1570.

DOI: $10.1007 / \mathrm{s} 10641-015-0382-8$

Pandolfi J.M., Bradbury R.H., Sala E., Hughes T.P., Bjorndal K.A., Cooke R.G., McArdle D., McClenachan L., Newman M.J.H., Paredes G., Warner R.R., Jackson J.B.C. 2003. Global trajectories of the long-term decline of coral reef ecosystems. Science 301 (5635): 955-958.

DOI: $10.1126 /$ science. 1085706 
Puentes Granada V., Masuda Y., Matsuoka T. 2004. Age and growth of the yellowbelly threadfin bream Nemipterus bathybius in Kagoshima Bay, southern Japan. Fisheries Science 70 (3): 497-506. DOI: $10.1111 / \mathrm{j} .1444-2906.2004 .00831 . \mathrm{x}$

Pyle R.L., Boland R., Bolick H., Bowen B.W., Bradley C.J., Kane C., Kosaki R.K., Langston R., Longenecker K., Montgomery A.D., Parrish F.A., Popp B.N., Rooney J., Smith C.M., Wagner D., Spalding H.L. 2016. A comprehensive investigation of mesophotic coral ecosystems in the Hawaiian Archipelago. PeerJ 4: e2475. DOI: $10.7717 /$ peerj. 2475

Randall J.E. 2001a. Mullidae. Goatfishes (surmullets). Pp. 3175-3200. In: Carpenter K.E., Niem V. (eds.) FAO species identification guide for fishery purposes. The living marine resources of the Western Central Pacific. Vol. 5. Bony fishes part 3 (Menidae to Pomacentridae). FAO, Rome.

Randall J.E. 2001b. Acanthuridae. Surgeonfishes (tangs, unicornfishes). Pp. 3653-3683. In: Carpenter K.E., Niem V. (eds.) FAO species identification guide for fishery purposes. The living marine resources of the Western Central Pacific. Vol. 6. Bony fishes part 4 (Labridae to Latimeriidae), estuarine crocodiles, sea turtles, sea snakes and marine mammals. FAO, Rome.

Rhodes K.L., Taylor B.M., Hernandez-Ortiz D., Cuetos-Bueno J. 2016. Growth and reproduction of the highfin grouper Epinephelus maculatus. Journal of Fish Biology 88 (5): 1856-1869.

DOI: $10.1111 / \mathrm{jfb} .12953$

Rhodes K.L., Tupper M.H. 2007. A preliminary market-based analysis of the Pohnpei, Micronesia, grouper (Serranidae: Epinephelinae) fishery reveals unsustainable fishing practices. Coral Reefs 26 (2): 335-344.

DOI: $10.1007 / \mathrm{s} 00338-007-0202-5$

Rhodes K.L., Tupper M.H., Wichilmel C.B. 2008. Characterization and management of the commercial sector of the Pohnpei coral reef fishery, Micronesia. Coral Reefs 27 (2): 443-454.

DOI: 10.1007/s00338-007-0331-X

Rhodes K.L., Warren-Rhodes K.A., Sweet S., HelgenbergerM.,JosephE.,BoyleL.N.,Hopkins K.D. 2015. Marine ecological footprint indicates unsustainability of the Pohnpei (Micronesia) coral reef fishery. Environmental Conservation 42 (2): 182-190. DOI: $10.1017 / \mathrm{S} 037689291400023 \mathrm{X}$

Roberts C.M., Polunin N.V.C. 1993. Marine reserves: Simple solutions to managing complex fisheries? Ambio 22 (6): 363-368.

Russell B.C. 1990. FAO species catalogue. Vol. 12. Nemipterid fishes of the world (threadfin breams, whiptail breams, monocle breams, dwarf monocle breams, and coral breams). Family Nemipteridae. An annotated and illustrated catalogue of nemipterid species known to date. FAO Fisheries Synopsis. FAO, Rome.
Sadovy Y., Shapiro D.Y. 1987. Criteria for the diagnosis of hermaphroditism in fishes. Copeia 1987 (1): 135-156. DOI: $\underline{10.2307 / 1446046}$

Sakai K. 2001. Kyphosidae. Sea chubs. Pp. 3290-3296. In: Carpenter K.E., Niem V. (eds.) FAO species identification guide for fishery purposes. The living marine resources of the Western Central Pacific. Vol. 5. Bony fishes part 3 (Menidae to Pomacentridae). FAO, Rome.

Sale P.F., Cowen R.K., Danilowicz B.S., Jones G.P., Kritzer J.P., Lindeman K.C., Planes S., Polunin N.V.C., Russ G.R., Sadovy Y.J., Steneck R.S. 2005. Critical science gaps impede use of no-take fishery reserves. Trends in Ecology and Evolution 20 (2): 74-80.

DOI: $10.1016 /$ j.tree.2004.11.007

Schemmel E.M., Donovan M.K., Wiggins C., Anzivino M., Friedlander A.M. 2016. Reproductive life history of the introduced peacock grouper Cephalopholis argus in Hawaii. Journal of Fish Biology 89 (2): 12711284.

DOI: $\underline{10.1111 / \mathrm{jfb} .13036}$

Shimose T., Nanami A. 2014. Age, growth, and reproductive biology of blacktail snapper, Lutjanus fulvus, around the Yaeyama Islands, Okinawa, Japan. Ichthyological Research 61 (4): 322-331.

DOI: $10.1007 / \mathrm{s} 10228-014-0401-3$

Shimose T., Nanami A. 2015. Age, growth, and reproduction of blackspot snapper Lutjanus fulviflammus (Forsskål 1775) around Yaeyama Islands, southern Japan, between 2010 and 2014. Journal of Applied Ichthyology 31 (6): 1056-1063.

DOI: $10.1111 /$ jai.12894

Taylor B.M., Gourley J., Trianni M.S. 2016. Age, growth, reproductive biology and spawning periodicity of the forktail rabbitfish (Siganus argenteus) from the Mariana Islands. Marine and Freshwater Research. DOI: $10.1071 / \mathrm{MF} 16169$

Taylor B.M., Rhodes K.L., Marshell A., McIlwain J.L. 2014. Age-based demographic and reproductive assessment of orangespine Naso lituratus and bluespine Naso unicornis unicornfishes. Journal of Fish Biology 85 (3): 901-916.

DOI: $\underline{10.1111 / \mathrm{jfb} .12479}$

Wallace R.A., Selman K. 1981. Cellular and dynamic aspects of oocyte growth in teleosts. American Zoologist 21 (2): 325-343.

DOI: $\underline{10.1093 / \mathrm{icb} / 21.2 .325}$

Takahashi H., Kobayashi K., Suzuki K. 1989. Gonadal morphology of threadfin breams, Nemipterus bathybius and $N$. virgatus: evidence of rudimentary hermaphroditism. Japanese Journal of Ichthyology 36 (1): 82-89.

DOI: $10.11369 / \mathrm{jij} 1950.36 .82$

Tokeshi M., Arakaki S., Daud J.R.P. 2013. Consuming diversity: Analysis of seasonal catch patterns in multispecies artisanal reef fisheries in North Sulawesi, Eastern Indonesia. Pacific Science 67 (1): 1-13. DOI: $\underline{10.2984 / 67.1 .1}$ 
Vitale F., Svedäng H., Cardinale M. 2006. Histological Young P.C., Martin R.B. 1985. Sex ratios and analysis invalidates macroscopically determined maturity ogives of the Kattegat cod (Gadus morhua) and suggests new proxies for estimating maturity status of individual fish. ICES Journal of Marine Science 63 (3): 485-492.

DOI: $10.1016 /$ j.icesjms.2005.09.001 hermaphroditism in nemipterid fish from northern Australia. Journal of Fish Biology 26 (3): 273-287. DOI: $\underline{10.1111 / \mathrm{j} .1095-8649.1985 . t b 04266 . x}$

Received: 23 December 2016

Accepted: 15 February 2017

Published electronically: 30 June 2017 